\title{
Biochemical characterization of diverse deep-sea anthozoan bioluminescence systems
}

\author{
Manabu Bessho-Uehara $^{1,2,3}$ (D) . Warren R. Francis ${ }^{4}$ (D) . Steven H. D. Haddock ${ }^{1}$
}

Received: 18 January 2020 / Accepted: 12 May 2020 / Published online: 9 July 2020

(c) The Author(s) 2020

\begin{abstract}
Bioluminescence, light produced by living organisms, is a common trait in the ocean. In benthic ecosystems in the deep-sea, octocorals are some of the most abundant luminous animals. Among luminous sessile organisms, the shallow-water sea pansy Renilla has been well studied for its chemistry and molecular biology. Aside from Renilla, however, little is known about the bioluminescent mechanisms of other anthozoans, especially deep-sea corals. In this study, we investigated the characteristics of bioluminescence in deep-sea anthozoans. The bioluminescent capabilities of Heteropolypus, Kophobelemnon, Paragorgia, and a hormathiid anemone are newly described. Coelenterazine, a substrate for bioluminescent reactions, was detected in extracts from octocorals. Coelenterazine-dependent luciferase activity was found in all the anthozoans. Moreover, immunoreactivity against Renilla luciferase was detected in protein extracts from the families Isididae, Alcyoniidae, Umbellulidae, Funiculinidae, Kophobelemnidae and Protoptilidae, suggesting that all luminous octocorals may share a common biochemical mechanism, which utilizes coelenterazine and Renilla-type luciferase. Our results support the hypothesis that the last common ancestor of all the octocorals was bioluminescent, and that bioluminescence evolved a minimum of six times in Cnidaria. Future studies with robust phylogenies, wide taxon sampling, and comparative transcriptome analyses could reveal the patterns of evolution of bioluminescence in octocorals and anthozoans. Our study provides fundamental observations of deep-sea corals and experimental evidence of their coelenterazine-dependent luciferase systems.
\end{abstract}

Responsible Editor: C. Voolstra.

Reviewed by S. Herrera and G. Williams.

Electronic supplementary material The online version of this article (https://doi.org/10.1007/s00227-020-03706-w) contains supplementary material, which is available to authorized users.

Steven H. D. Haddock

haddock@mbari.org

1 Monterey Bay Aquarium Research Institute, Moss Landing, CA, USA

2 Institute for Advanced Research, Nagoya University, Furo-cho, Chikusa-ku, Nagoya, Aichi 464-8601, Japan

3 Graduate School of Bioagricultural Sciences, Nagoya University, Furo-cho, Chikusa-ku, Nagoya, Aichi 464-8601, Japan

4 Department of Biology, University of Southern Denmark, Odense, Denmark

\section{Introduction}

Class Anthozoa is a diverse group of cnidarians containing 7500 species, including sea anemones and corals. They are found throughout marine environments, and provide structure that harbors biodiversity (Bellwood and Hughes 2001; Daly et al. 2007). Optical and structural variability of coral reefs provides ecological niches resulting in the evolution of morphologically diversified animals as represented in the Great Barrier Reef. In the deep sea, octocorals (predominantly pennatulaceans and gorgonians such as bamboo and primnoid corals) and stony corals (Scleractinia), also contribute to the diversity in their environments (Roberts et al. 2006; Watling et al. 2011).

Bioluminescence, light emission from living organisms, was noted in sea pens in an early published account by Boussuet (1558) (as cited in Williams 1999), subsequently by Pratje (1923) and Harvey (1952), and more recently documented in Anthozoa by Herring (1987), Williams (2001, 2003), and Johnson et al. (2012). The luminous anthozoan species are taxonomically sparsely reported among two subclasses, four orders, and 17 families 
according to the classification of WoRMS (Cordeiro et al. 2019). Order Actiniaria and Zoantharia in subclass Hexacorallia include four luminous genera: Epizoanthus, Savalia (formerly Gerardia), Parazoanthus, and an unidentified Hormathiidae sea anemone. Order Alcyonacea in subclass Octocorallia includes ten luminous genera; Acanthogorgia, Anthomastus, Eleutherobia, Chrysogorgia, Iridogorgia, Isidella, Keratoisis, Lepidisis, Primnoisis, and Thouarella. Order Pennatulacea in subclass Octocorallia includes 16 luminous genera: Funiculina, Halipteris, Pennatula, Pteroeides, Ptilosarcus, Distichoptilum, Protoptilum, Renilla, Stachyptilum, Umbellula, Cavernularia, Veretillum, Actinoptilum, Acanthoptilum, Stylatula, and Virgularia. In the time since Herring (1987) listed luminous Alcyonacea, some species have been reclassified to different genera. For example, Anthomastus ritteri has been reclassified as Heteropolypus ritteri (Molodtsova 2013), and it remains unclear which species of the parent family might be bioluminescent. Recent phylogenetic analyses suggest polyphyly of Alcyonacea (Quattrini et al. 2018), but we still do not have a reliable phylogeny including a rich enough set of luminous species to fully evaluate the origins of bioluminescence in this lineage. Hence, in this study, we follow the classification presently accepted by WoRMS (marinespecies.org).

A typical chemical reaction producing bioluminescence involves an enzyme (generally called a luciferase), a substrate (luciferin), and oxygen with or without cofactors (Haddock et al. 2010). The shallow-water sea pansy Renilla reniformis (Pennatulacea: Renillidae) is the most biochemically studied anthozoan. The Renilla luciferase acts upon coelenterazine, a luciferin which is used among a variety of luminous marine animals (Inoue et al. 1977), in the presence of dissolved oxygen to emit blue light (maximum wavelength $=480 \mathrm{~nm}$ ) without other cofactors (Matthews et al. 1977; Lorenz et al. 1991). Other associated molecules such as a green fluorescent protein (GFP), a coelenterazine binding protein (CBP), and coelenterazine sulfate have been identified and characterized in Renilla (Inoue et al. 1977; Ward and Cormier 1979; Kumar et al. 1990; Inouye 2007). The homologous genes encoding the luciferase, GFP, and CBP have also been also identified from the shallow-water sea cactus Cavernularia obesa (Vertillidae) (Ogoh 2012; Ogoh et al. 2013). Coelenterazine-dependent luciferase activity was also reported in other Pennatulacea (Cormier et al. 1973). However, little is known about the biochemistry of bioluminescence in the other anthozoans, especially deep-sea species.

In this study, we examined the bioluminescence of deep-sea anthozoans and found one hexacoral and three octocorals to be bioluminescent for the first time. All the anthozoans tested were positive for possessing coelenterazine and coelenterazine-dependent luciferases. Moreover, immunoreactivity against Renilla luciferase was detected in Alcyonacea corals. These results suggest that extant Octocorallia species share a homologous bioluminescent mechanism.

\section{Materials and methods}

\section{Samples}

Animals were collected along the coast of California using the remotely operated vehicle (ROV) Doc Ricketts operated from RV Western Flyer from the Monterey Bay Aquarium Research Institute (MBARI) between 2018 and 2019 under California Fish and Wildlife Permit SC-4029 and Specific Use Permit S-191140006-19114-001 to SHDH. Lepidisis sp. (Fig. 1a, b), Isidella tentaculum (Fig. 2a-c), Heteropolypus ritteri (Fig. 3a, b), Kophobelemnon sp. (Fig. 4a, b), Paragorgia arborea (Fig. 5a), Umbellula sp. (Fig. 6a, b), Distichoptilum gracile (Fig. 7a), Funiculina sp. (Fig. 8a), Pennatula sp. (Fig. 9a), and a Hormathiid (Fig. 10a) were sampled by the ROV. For some samples, specimens were held by the robotic arm of the ROV and agitated in situ during collection to stimulate bioluminescence, which could be recorded by a low-light sensitive color camera. Once aboard the ship, collected specimens were kept in the dark at $4{ }^{\circ} \mathrm{C}$ until in vivo bioluminescent spectral measurements and photography, followed by being frozen in liquid nitrogen. Specimens were morphologically identified by Steven Haddock, Kyra Schlining, or Lonny Lundsten, and subsamples were frozen for DNA barcoding. The specific depths of the animals collected are described in Table 1.

\section{Luciferase extraction and assay}

Luciferase activity was measured using coelenterazine (Prolume Ltd., Pinetop, AZ, USA) in a Tecan Infinite 200 platereader (TECAN, Männedorf, Switzerland) running i-control software. To extract luciferase, frozen tissues $(100-400 \mathrm{mg}$ ) were homogenized in $2 \mathrm{~mL}$ of $200-\mathrm{mM}$ Tris-HCl, 50-mM EDTA; pH 7.6. The homogenate was centrifuged at $15,000 \times g$ at $4{ }^{\circ} \mathrm{C}$ for $10 \mathrm{~min}$. The buffer in the supernatant was replaced by $20-\mathrm{mM}$ Tris- $\mathrm{HCl}, 5-\mathrm{mM}$ EDTA; pH 7.6 using PD-10 desalting columns (GE Healthcare, Chicago, IL, USA). The $50 \mu \mathrm{L}$ of protein extracts were placed in the wells of 96-well plate and the light-emitting reaction was assayed by injection of $50 \mu \mathrm{L}$ of $1-\mu \mathrm{M}$ coelenterazine. As non-luciferase protein control, $107 \mu \mathrm{g} / \mathrm{mL}$ of bovine serum albumin (BSA) was used.

To characterize luciferase activity, we tested two $\mathrm{pH}$ conditions and three common cation species. The crude luciferase extracts were assayed with sodium chloride, calcium chloride, or magnesium chloride at $\mathrm{pH} 7.5$ or 8.6. Fifty 


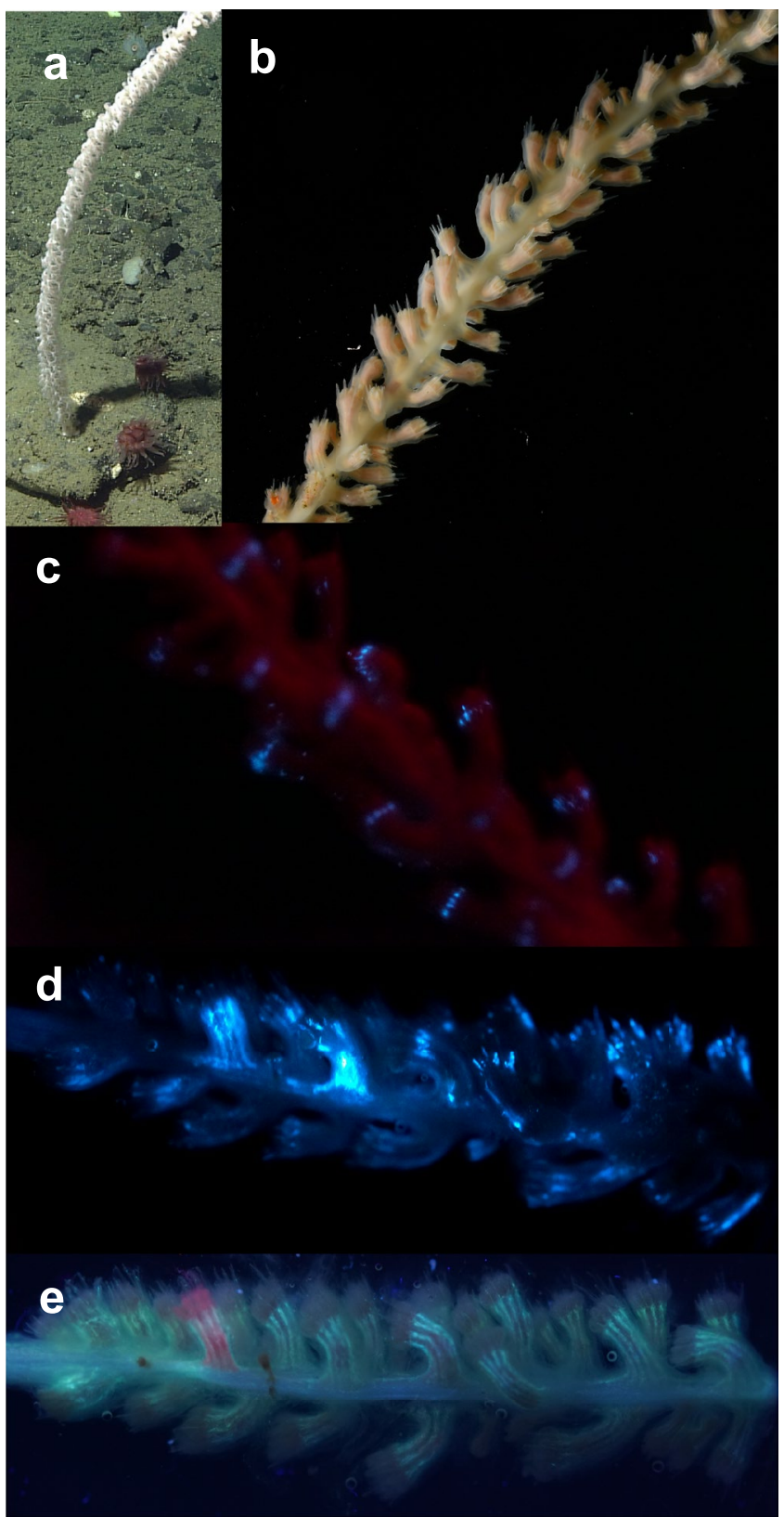

Fig. 1 Lepidisis sp. a Frame grab of ROV dive at $1288 \mathrm{~m}$. b The specimen in the lab under white light. c Bioluminescence stimulated mechanically under red light. ISO $51200, \mathrm{~F} / 2.8$, exposure time $1 / 10 \mathrm{~s}$. d Bioluminescence stimulated with $\mathrm{KCl}$. ISO 16000, F/2.8, exposure time $0.625 \mathrm{~s}$. e Fluorescence under UV light. $\mathbf{f}$ Bioluminescence spectrum smoothed by Savitzky-Golay method. g Coelenterazine

microliters of protein extracts were mixed with $10 \mu \mathrm{L}$ of $0.5-\mathrm{M}$ salt in $0.5-\mathrm{M}$ Tris- $\mathrm{HCl}$ buffer at $\mathrm{pH} 7.5$ or 8.6 in the well of 96-well plate, and the reaction was initiated by injection of $40 \mu \mathrm{L}$ of $1-\mu \mathrm{M}$ coelenterazine.

\section{f}
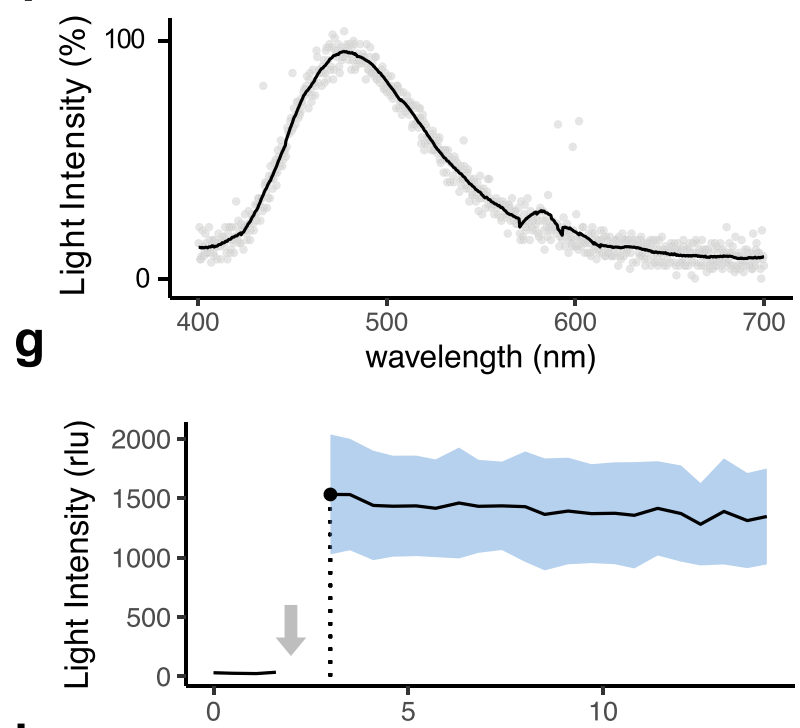

h
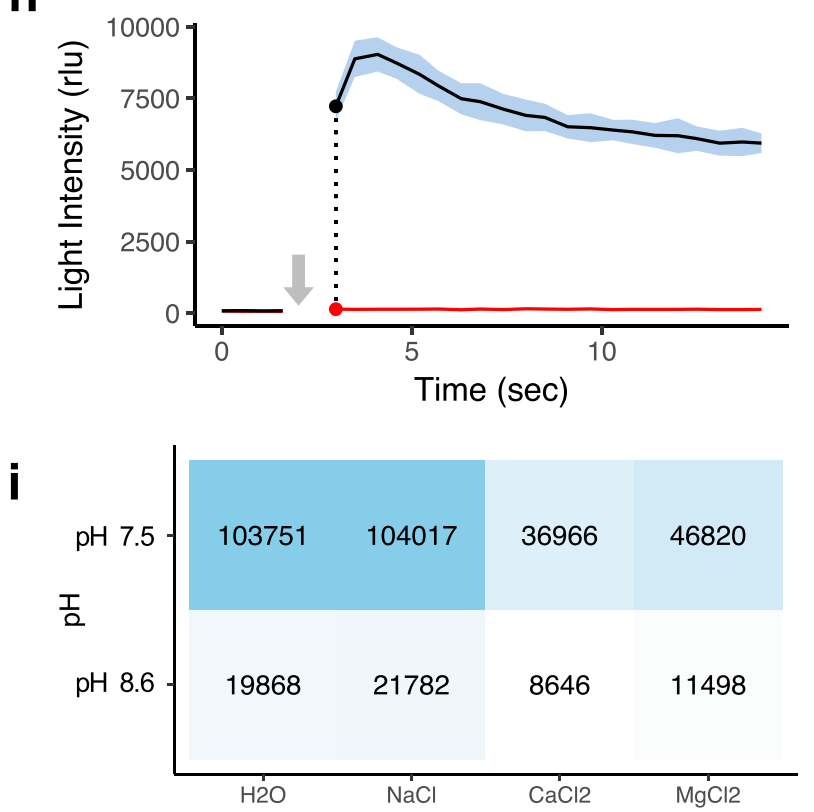

assay. The luciferin extract was mixed with $1 \mathrm{ng} / \mu \mathrm{L}$ Renilla luciferase at $t=2 \mathrm{~s}$ (arrow). Standard deviation $( \pm \mathrm{SD})$ is shown as a ribbon graph. h Luciferase assay. The protein extract was mixed with $1 \mu \mathrm{M}$ coelenterazine at $t=2 \mathrm{~s}$ (arrow). Coelenterazine added to BSA (red) is used as negative control. $\mathbf{i}$ Characterization of luciferase. Values are measured in relative light unit in the luminometer (rlu)

\section{Luciferin extraction and assay}

The coelenterazine content in the animal was quantified by comparison with native coelenterazine using commercially available recombinant Renilla luciferase (Prolume Ltd) in the luminometer. The frozen tissues $(40 \mathrm{mg}-150 \mathrm{mg}$ ) were homogenized in $200 \mu \mathrm{L}$ of $99.5 \% \mathrm{EtOH}$. The homogenate 


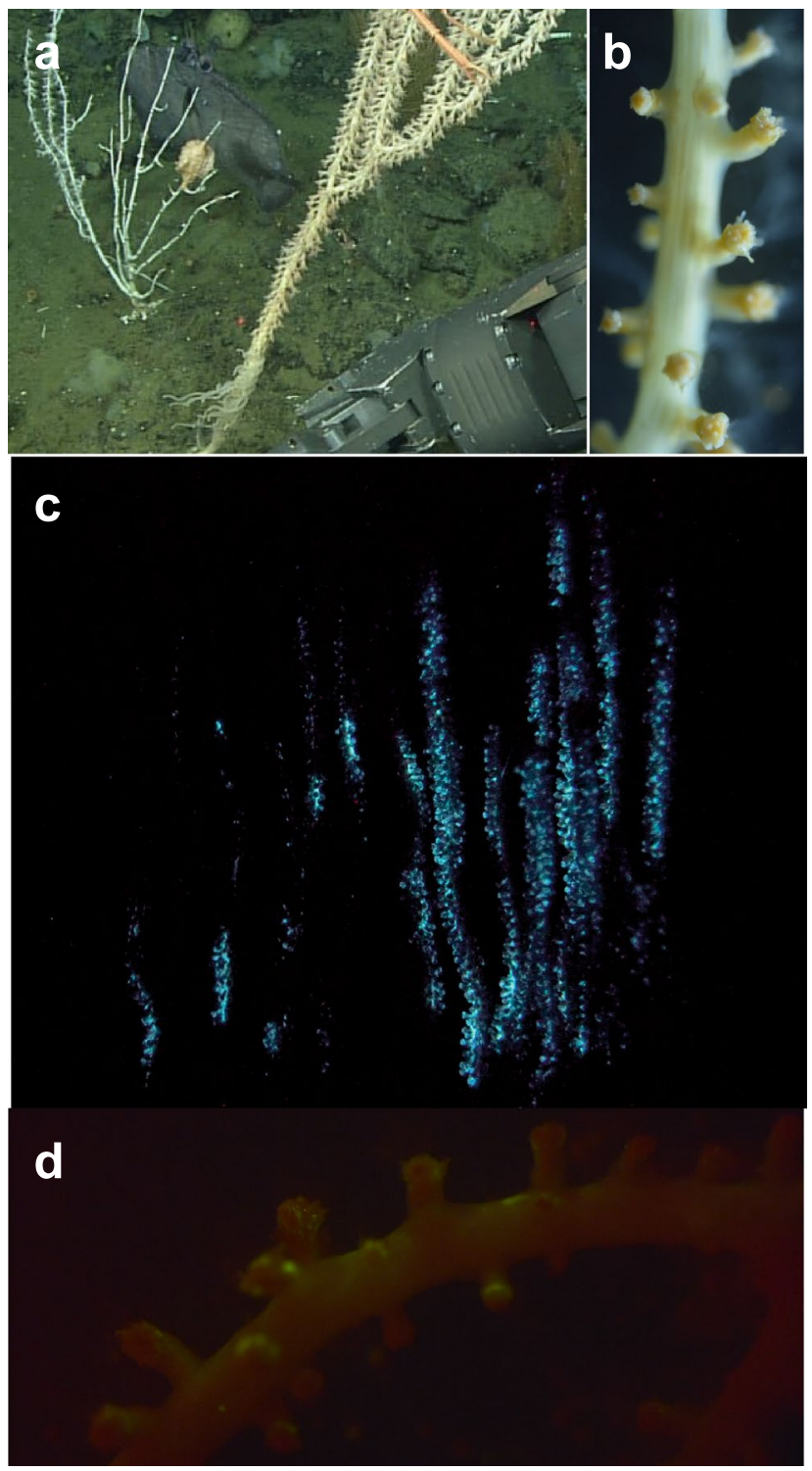

Fig. 2 Isidella tentaculum. a Frame grab of ROV dive at $1224 \mathrm{~m}$. b The specimen in the lab under white light. c Bioluminescence stimulated mechanically. Frame grab of low-light camera on the ROV. d

was centrifuged at $15,000 \times g$ at $4{ }^{\circ} \mathrm{C}$ for $10 \mathrm{~min}$. The supernatant was filtered using a $0.45-\mu \mathrm{m}$ membrane filter (MilliporeSigma, Burlington, MA, USA). Ten microliters of the filtered luciferin extract were diluted with $90 \mu \mathrm{L}$ of water and placed in a well of a 96-well plate. The luminescent reaction was initiated by injecting $100 \mu \mathrm{L}$ of $100-\mathrm{pg} / \mu \mathrm{L}$ Renilla luciferase in the 20-mM Tris-HCl, 5-mM EDTA, $\mathrm{pH}$ 7.6.

\section{Western blotting}

Immunoreactivity was tested using anti-Renilla luciferase antibody to understand if the specimen possesses a luciferase homologous to Renilla luciferase. Protein samples
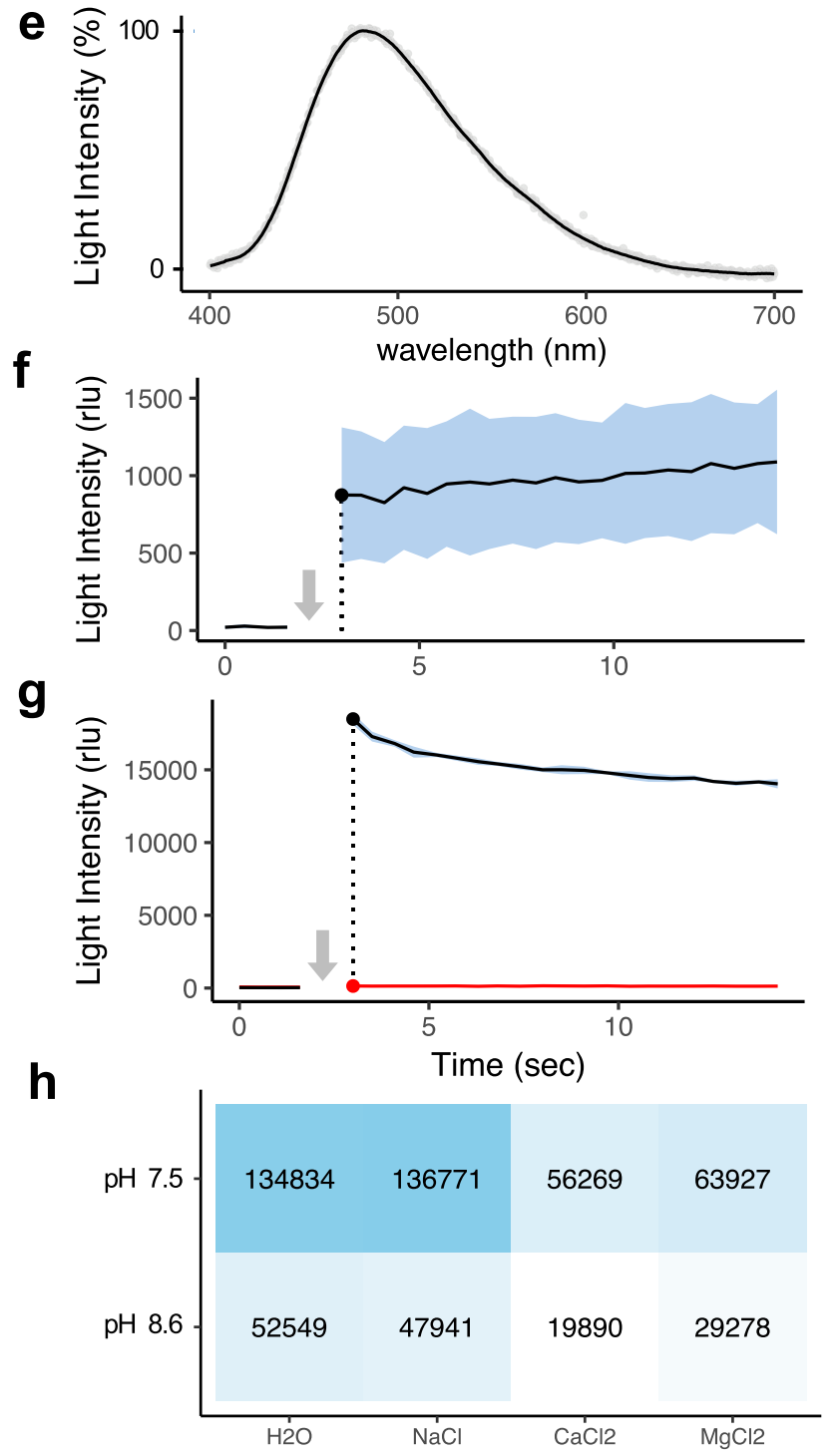

Fluorescence under blue light through the yellow filter. e Bioluminescence spectrum. f Coelenterazine assay. $\mathbf{g}$ Luciferase assay. $\mathbf{h}$ The effects of $\mathrm{pH}$ and ions

were reduced with SDS sample buffer containing dithiothreitol (62.5-mM Tris-HCl, pH 6.8, 2\% SDS, $10 \%$ glycerol, $0.1 \mathrm{w} / \mathrm{v} \%$ bromophenol blue, $100-\mathrm{mM}$ dithiothreitol at the final concentration) and were separated by sodium dodecyl sulfate-polyacrylamide gel electrophoresis (SDSPAGE) using Novex 10-20\% polyacrylamide gradient gel (Thermo Scientific, Waitham, MA). The separated protein in the gel was blotted onto a PVDF membrane using XCell II blot Module (Thermo Scientific) at $42 \mathrm{~V}$ for $90 \mathrm{~min}$. The blotted membrane was treated with Pierce Western Blot Signal Enhancer (Thermo Scientific) followed by blocking with 5\% BSA in Tris-buffered saline with $0.1 \%$ Tween 20 (TBS$\mathrm{T})$ for $1 \mathrm{~h}$ at room temperature and subsequently incubated 


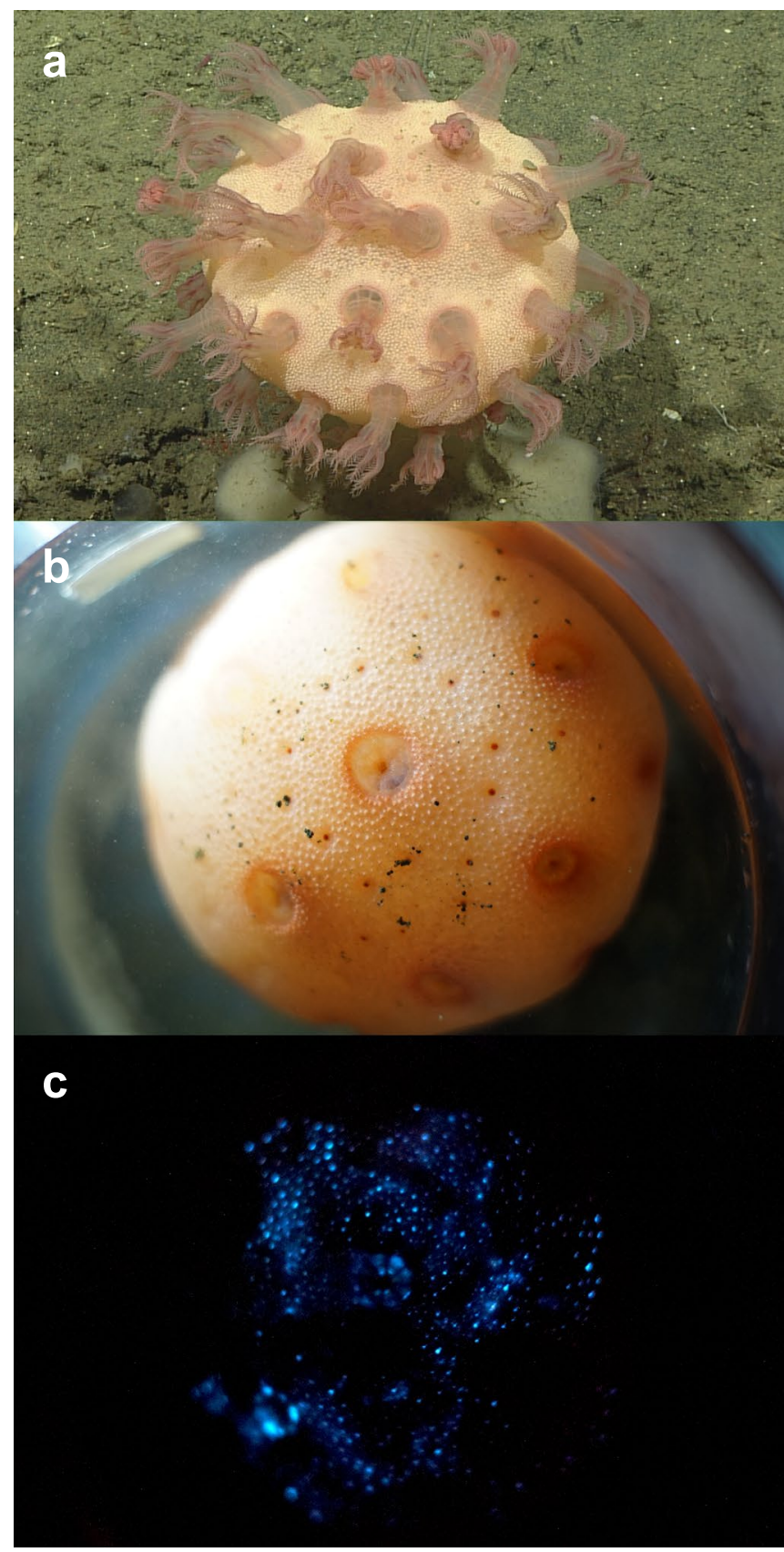

Fig. 3 Heteropolypus ritteri. a Frame grab of ROV dive at $1031 \mathrm{~m}$. b The specimen in the lab under white light. c The bioluminescence stimulated with $\mathrm{KCl}$ in the same frame of $\mathbf{b}$. ISO $25600, \mathrm{~F} / 2.8$, expo-

with $1.14 \mu \mathrm{g} / \mathrm{mL}$ of anti-Renilla luciferase rabbit antibody (Invitrogen, catalog number PA5-32,210) for $16 \mathrm{~h}$ at $4{ }^{\circ} \mathrm{C}$. The blot was washed three times with TBS-T for $10 \mathrm{~min}$ each at room temperature. Goat anti-rabbit IgG horseradish peroxidase-conjugated secondary antibody (Promega) was incubated with the blot for $1 \mathrm{~h}$ at room temperature, and the blot was washed three times with TBS-T. Immunoreactivity was visualized by chemiluminescence using SuperSignal West Pico PLUS Chemiluminescent Substrate (Thermo
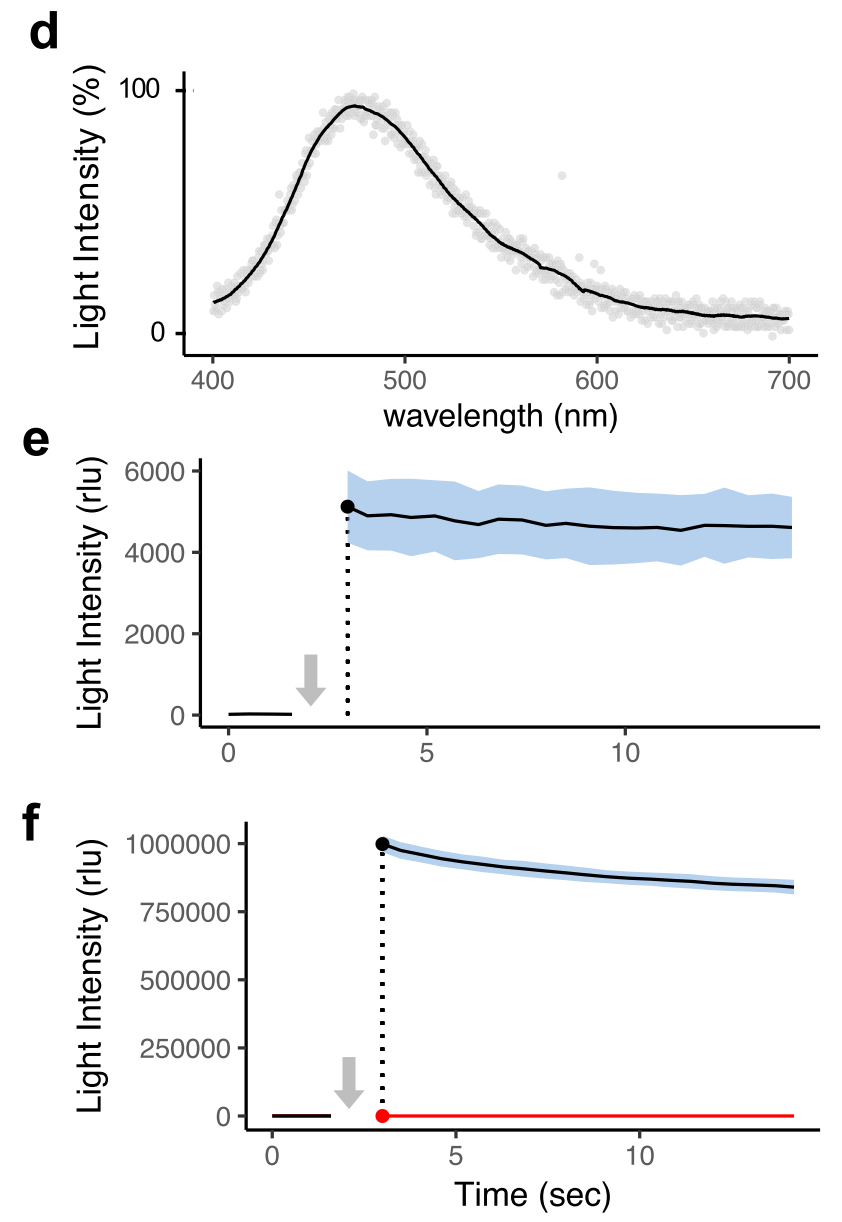

g

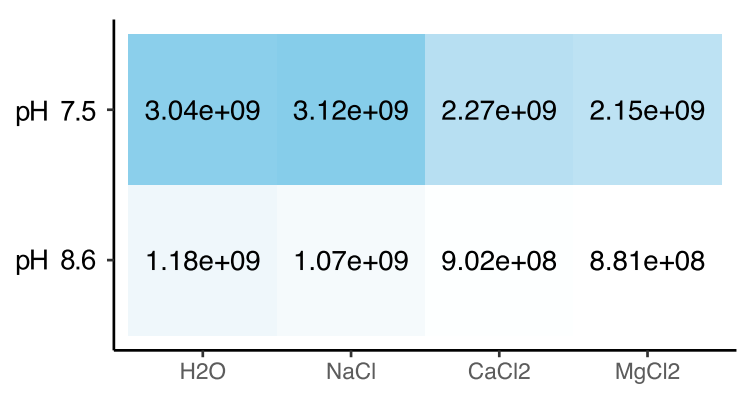

sure time $10 \mathrm{~s}$. d In vivo bioluminescence spectra. e Coelenterazine assay. $\mathbf{f}$ Luciferase assay. $\mathbf{g}$ The effects of $\mathrm{pH}$ and ions

Scientific). SuperSignal Molecular Weight Protein Ladder (Thermo Scientific) was used as protein standard ladder.

\section{Spectra measurement}

In vivo bioluminescent spectra were measured using an Ocean Optics QE65000 spectrometer (CCD detector, $300-800 \mathrm{~nm}$ range at $\sim 0.4 \mathrm{~nm} / \mathrm{pixel}$ ) (Ocean Optics, Largo, FL) with attached quartz fiber optic. The 


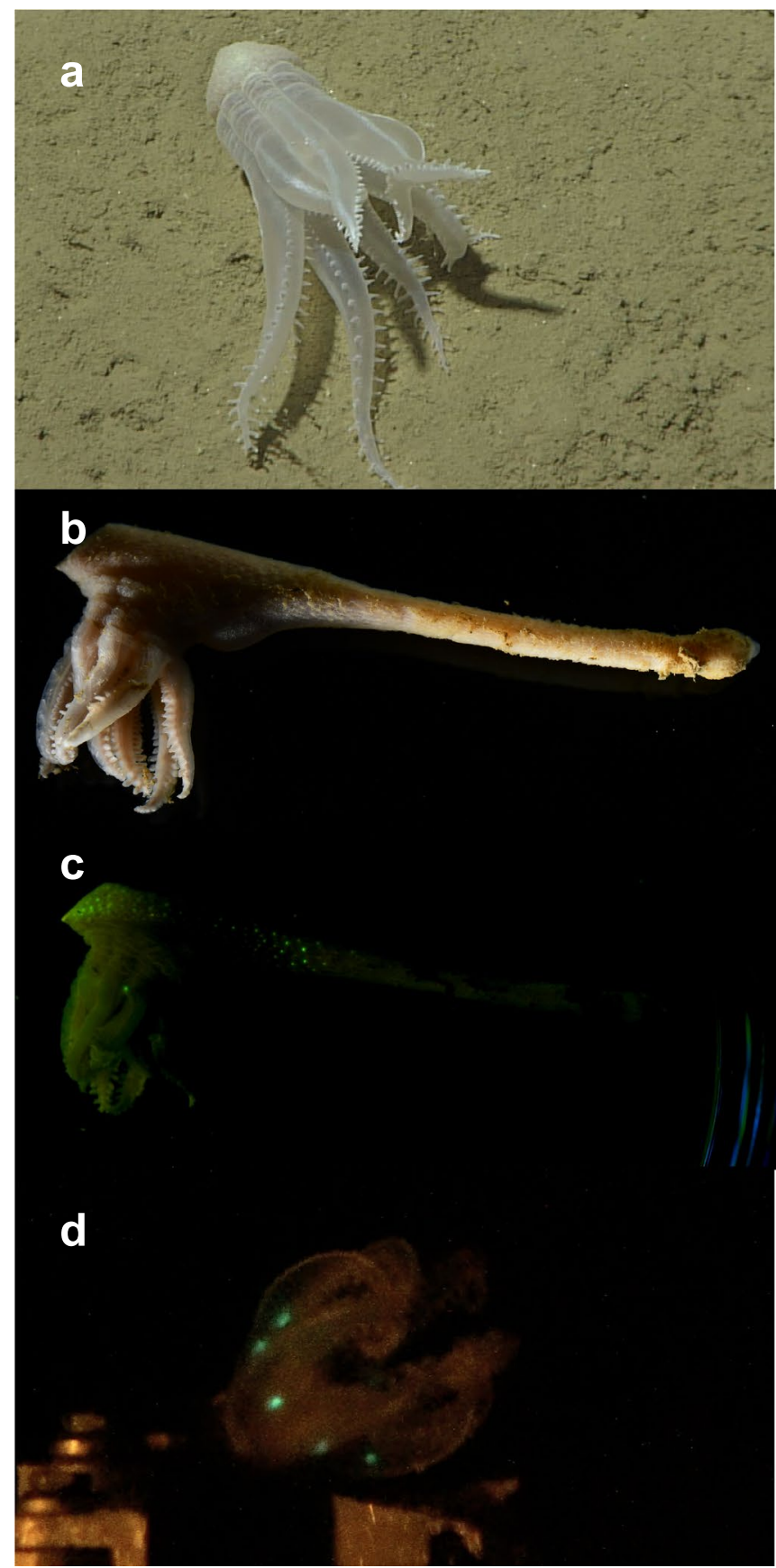

Fig. 4 Kophobelemnon sp. a frame grab of ROV dive at $3980 \mathrm{~m}$. b The specimen in the lab under white light. c The fluorescence under blue light with yellow filter. d In situ bioluminescence taken by the camera on ROV. The green light is emitted from the spots between

specimens were stimulated mechanically (gently touched with a pipet) or chemically $\left(\mathrm{KCl}\right.$ or $\left.\mathrm{CaCl}_{2}\right)$ for bioluminescence. To collect the spectra data, we used the program brizzy (https://github.com/conchoecia/brizzy) modified from the associated Ocean Optics SeaBreeze API. The in vitro bioluminescent spectra were measured e

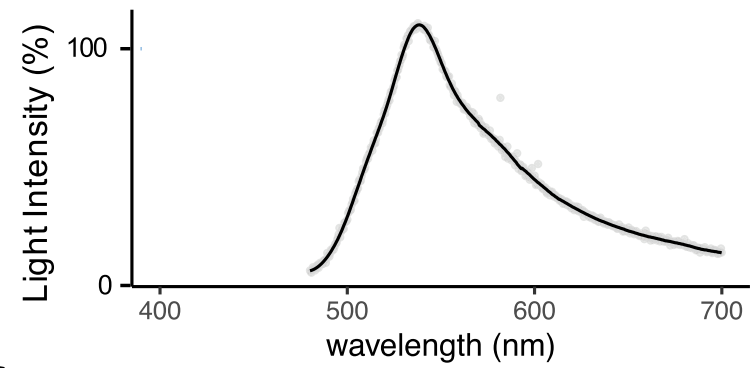

f

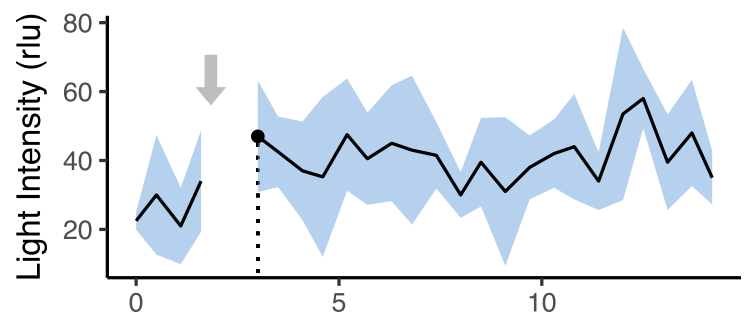

$\mathbf{g}$

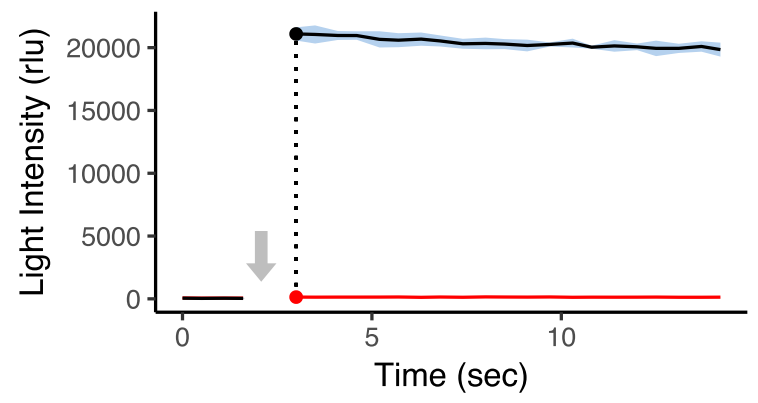

h

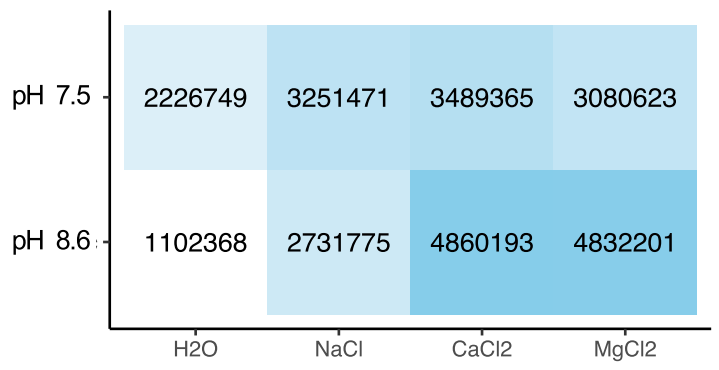

tentacles. e Fluorescence spectra. f Coelenterazine assay. g Luciferase assay. $\mathbf{h}$ The effect of $\mathrm{pH}$ and ions. Note the more basic condition has higher emission only in the presence of divalent cations

from $500 \mu \mathrm{L}$ of protein extract mixed with $1 \mu \mathrm{L}$ of $1-\mathrm{mM}$ coelenterazine. In vivo fluorescent spectra were measured under blue excitation through a yellow blue-blocking filter. The obtained spectra were smoothed in R software using a Savitzky-Golay filter with parameters: filter order $=3$, filter length $=61$. 


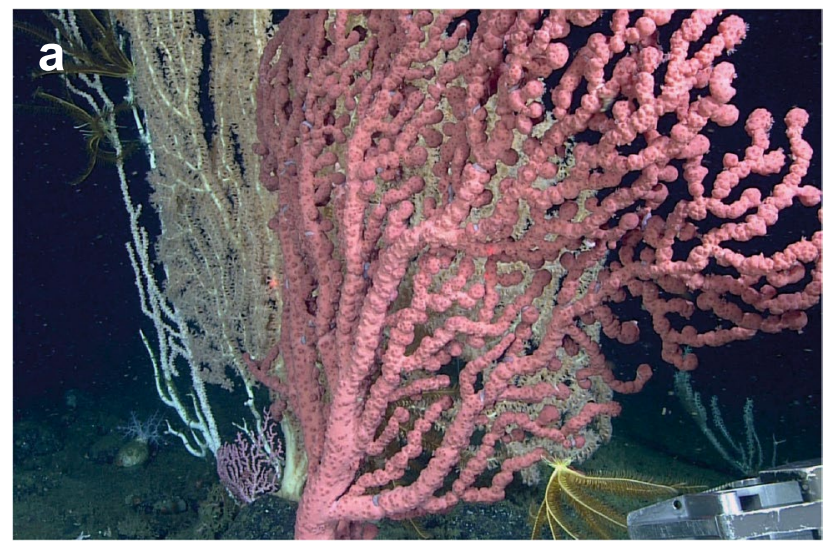

b

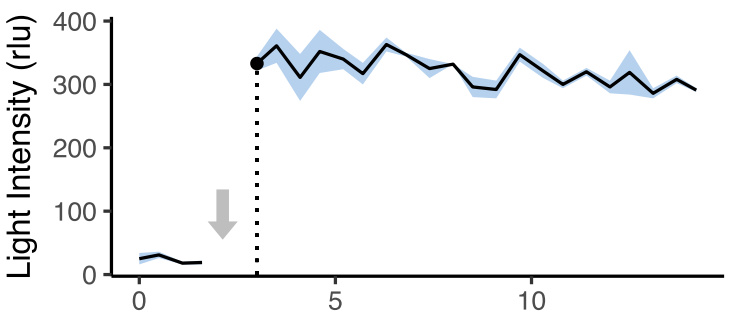

C

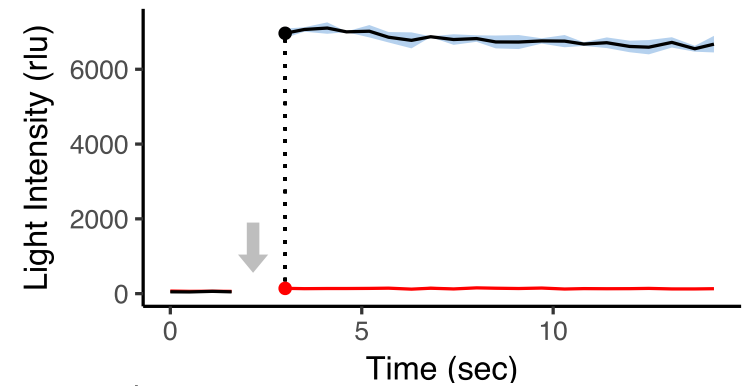

d

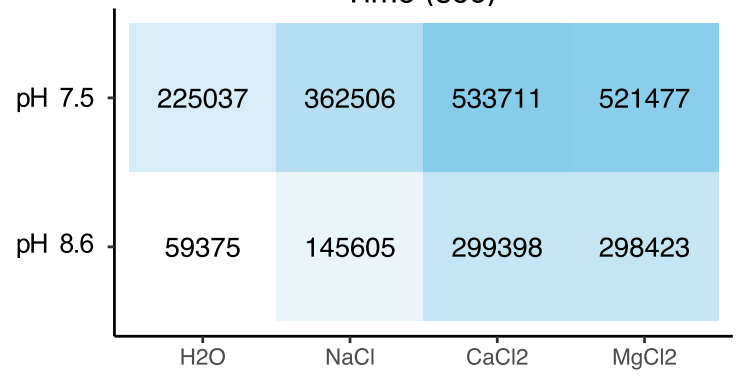

Fig. 5 Paragorgia arborea. a Frame grab of ROV dive at $1171 \mathrm{~m}$. b Coelenterazine assay. c Luciferase assay. d The effects of $\mathrm{pH}$ and ions

\section{DNA extraction and sequencing}

The nucleotide sequences of the specimens were sequenced and deposited in GenBank (Table 1) as DNA reference barcodes. DNA was extracted from 40 to $60 \mathrm{mg}$ of frozen sample using QIAamp blood and tissue extraction kit (QIAGEN, Hilden, Germany). The nuclear gene ribosomal RNA 28S for octocorals was amplified by polymerase chain reaction (PCR) with forward primer, LSUD1F 5'-ACCCGCTGA
ATTTAAGCATA-3'; and reverse primer, D3AR 5'-ACG AACGATTTGCACGTCAG-3' (Scholin et al. 1994). The mitochondrial gene cytochrome oxidase subunit III (COIII) for hormathiid anemone was amplified by PCR with forward primer, COIIIF 5'-CATTTAGTTGATCCTAGGCCT TGACC-3'; and reverse primer, COIIIR 5'-CAAACCACA TCTACAAAATGCCAATATC-3' (Geller and Walton 2001). The isolated gene fragments were sequenced by capillary sequencer 3500xL Genetic Analyzer Sanger (Applied Biosystems, Foster City, CA, USA). The sequences were deposited in NCBI and the BOLD System. The accession numbers for GenBank are listed in Table 1.

\section{Homology search for luciferase and phylogenetic analysis}

Luciferase homologs were sought by BLAST searches against publicly available genome and transcriptome data. For all searches, Renilla reniformis luciferase was used as the query sequence (SwissProt accession: P27652). Genomic data of Renilla muelleri (Jiang et al. 2019) and Dendronephthya gigantea (Jeon et al. 2019) were downloaded from the websites indicated in their respective papers. Transcriptome data were used from Gorgonia ventalina (Burge et al. 2013), Leptogorgia sarmentosa (Romiguier et al. 2014), Corallium rubrum (Pratlong et al. 2015), Heliopora coerulea (Hongo et al. 2017), Tubipora musica, Sinularia cruciata, Pinnigorgia flava (Conci et al. 2019), Anthomastus sp., Cerianthid sp., Keratoisid sp., Scleronephthya sp. (Zapata et al. 2015), and Pennatula rubra (Simion et al. 2017). Other homologs were taken from previous analyses of this protein family by Delroisse et al. (2017).

Sequences were aligned with MAFFT v7.313 (Katoh and Standley 2013), using the LINSI options (equivalent tomaxiterate 1000-localpair). Phylogenetic tree was generated with IQTREE v1.6.12 (Nguyen et al. 2015), with 1000 fast bootstrap replicates (-bb 1000) and protein model LG with 6 rate categories $(\mathrm{LG}+\mathrm{R} 6)$.

\section{Results and discussion}

\section{Lepidisis sp.}

The luminescence of Lepidisis sp. (Fig. 1a, b) was evoked by agitation using the ROV manipulator. The blue-light emission propagated as a wave (Electronic Supplementary Material Video). The light intensity was especially strong on the polyps, but the whole body including along the stem is capable of light emission. In the lab, when one of the polyps of the specimen was stimulated, blue flashes were emitted from the tips of polyps and the light was distributed as a wave, from the point disturbed to the 


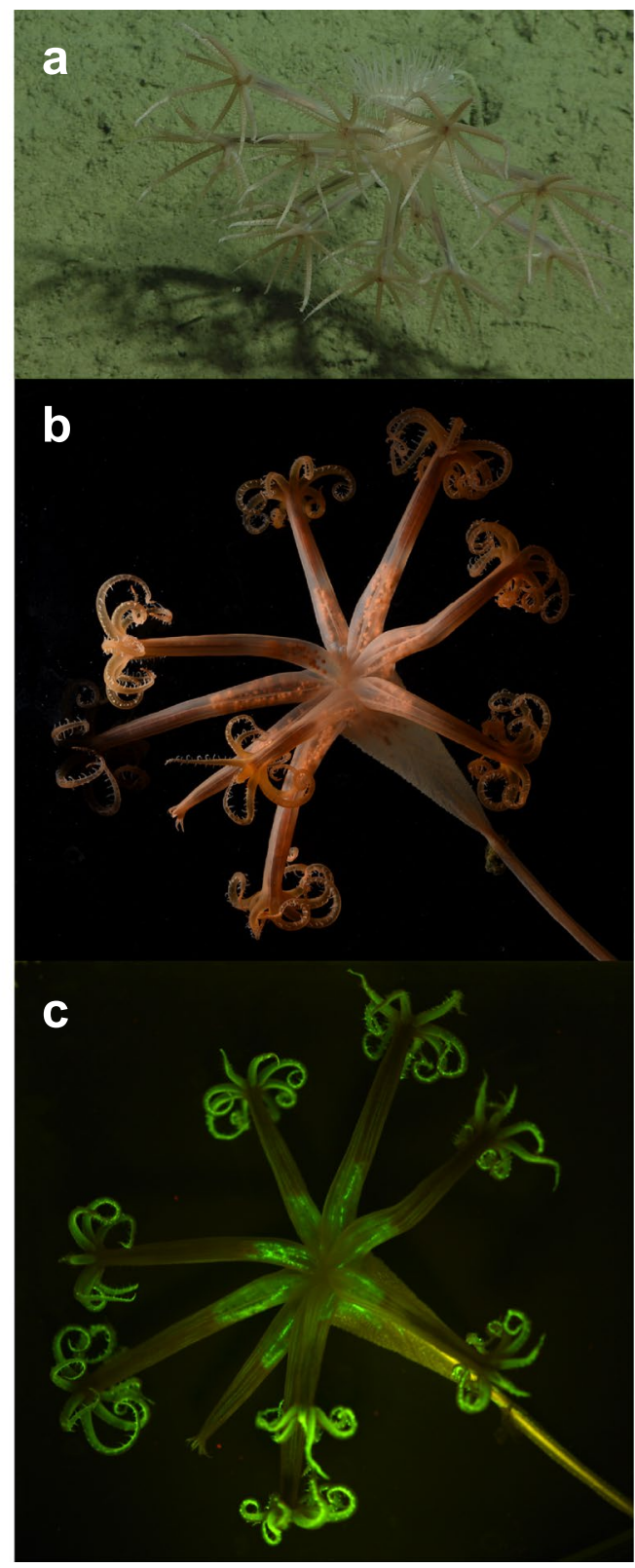

d

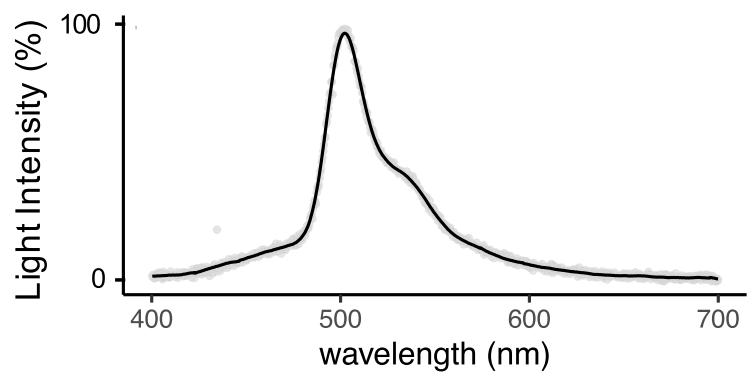

e

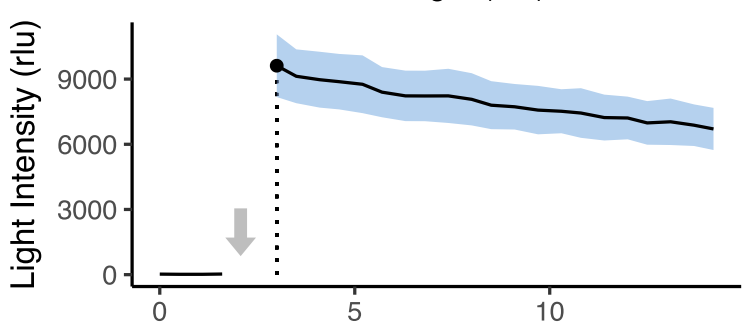

f

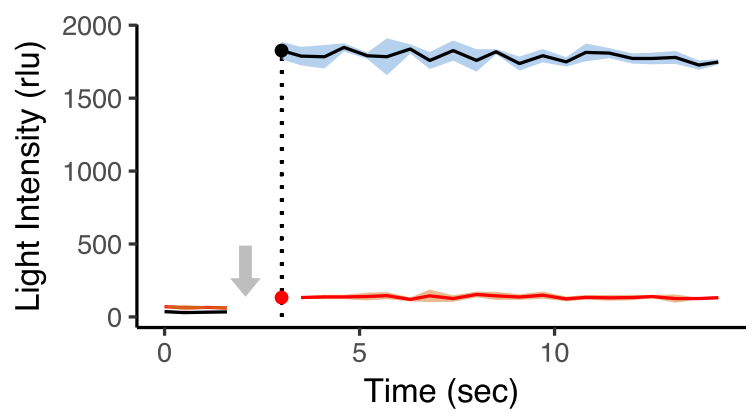

g

Fig. 6 Umbellula sp. a Frame grab of ROV dive at $3226 \mathrm{~m}$. b The specimen in the lab under white light. $\mathbf{c}$ The fluorescence under blue light through a yellow filter. $\mathbf{d}$ Bioluminescence spectrum, with char-

acteristic GFP shape. e Coelenterazine assay. f Luciferase assay. g The effects of $\mathrm{pH}$ and ions

tip of the next polyp (Fig. 1c, Electronic Supplementary Material Video). This observation was consistent with that of Lepidisis olapa by Muzik (1978). Chemical stimulation using $\mathrm{KCl}$ made the whole specimen glow continuously for a few minutes without its natural kinetics (Fig. 1d). The specimen had green fluorescence localized along the stem and in polyps under UV excitation (wavelength $365 \mathrm{~nm}$ ) (Fig. 1e). Interestingly, a few polyps emitted pink fluorescence. The peak wavelength of the bioluminescent spectrum was at $477 \mathrm{~nm}$ (Fig. 1f), corresponding to the light

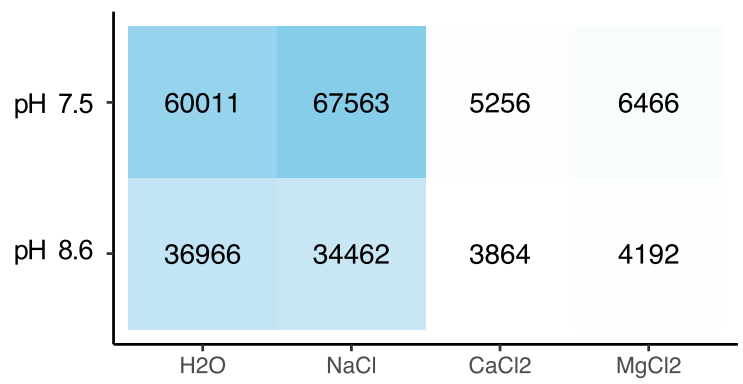

of Lepidisis sp. collected from Bahamian Islands (Johnsen et al., 2012).

Ethanol extract was positive for coelenterazine when assayed with Renilla luciferase (Fig. 1g). Light was produced upon the injection of the coelenterazine-specific luciferase, indicating the presence of coelenterazine. The assay for luciferase activity in crude protein extract was positive upon injection with 1- $\mu \mathrm{M}$ coelenterazine (Fig. 1h). Light was produced upon the injection of the coelenterazine, suggesting the presence of coelenterazine-dependent luciferase. Upon injection by coelenterazine, light intensity of the 


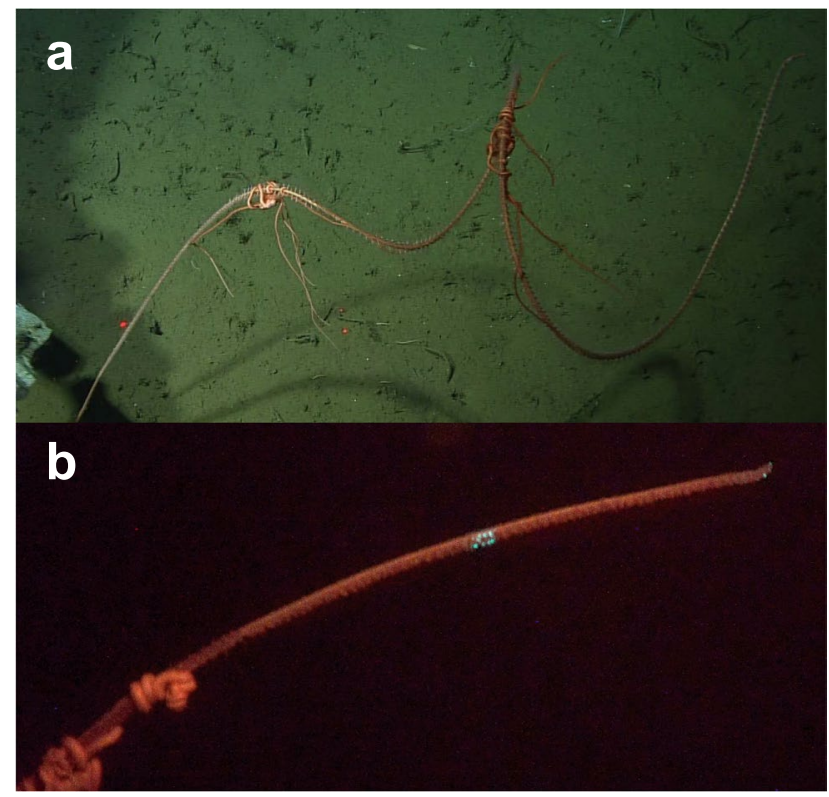

\section{e}

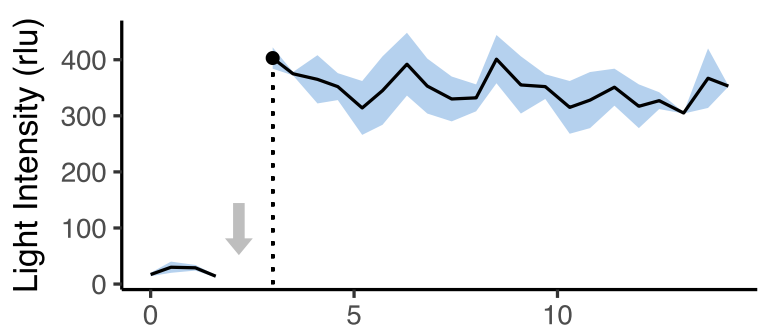

f
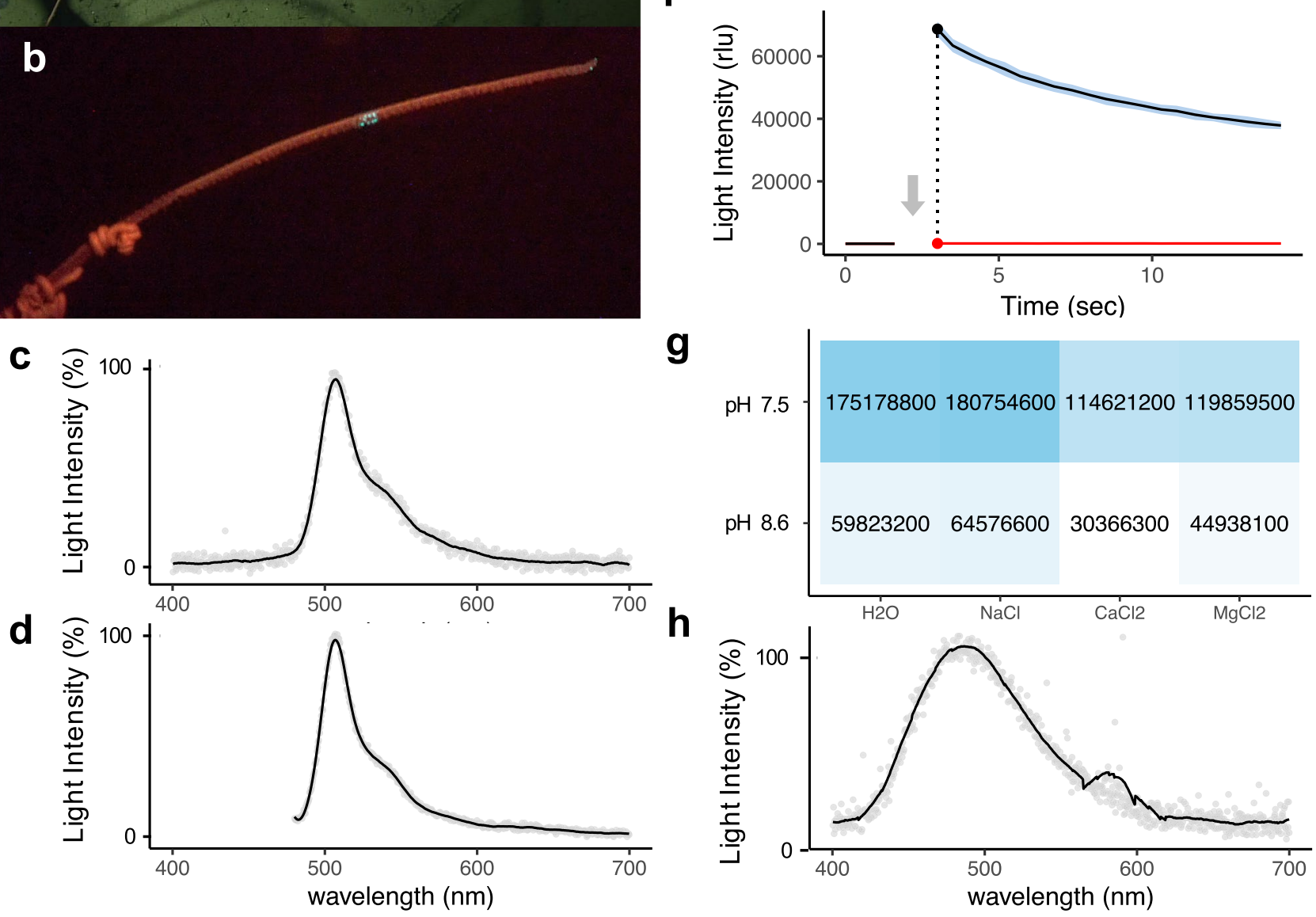

g

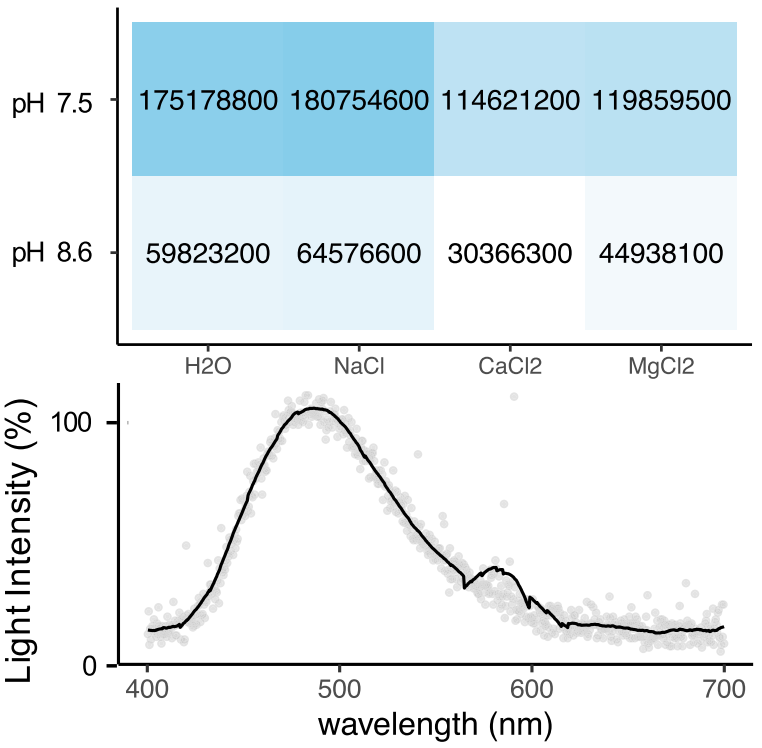

filter. e Coelenterazine assay. $\mathbf{f}$ Luciferase assay. $\mathbf{g}$ The effects of $\mathrm{pH}$ and ions. $\mathbf{h}$ In vitro bioluminescent spectrum

manipulator or by hand (Fig. 2c). The specimen secreted luminous mucus upon strong stimulation (Electronic Supplementary Material Video). Etnoyer reported that I. tentaculum emits green-blue light when the specimen was agitated by the ROV manipulator (Etnoyer 2008). Weak green fluorescence was observed under blue light through a yellow filter, though it did not clearly correspond to the color of bioluminescence (Fig. 2d). The peak wavelength of the bioluminescent spectrum was $483 \mathrm{~nm}$ (Fig. 1e), close to the $480 \mathrm{~nm}$ peak observed in the Atlantic Isidella sp. (Johnsen et al. 2012). 

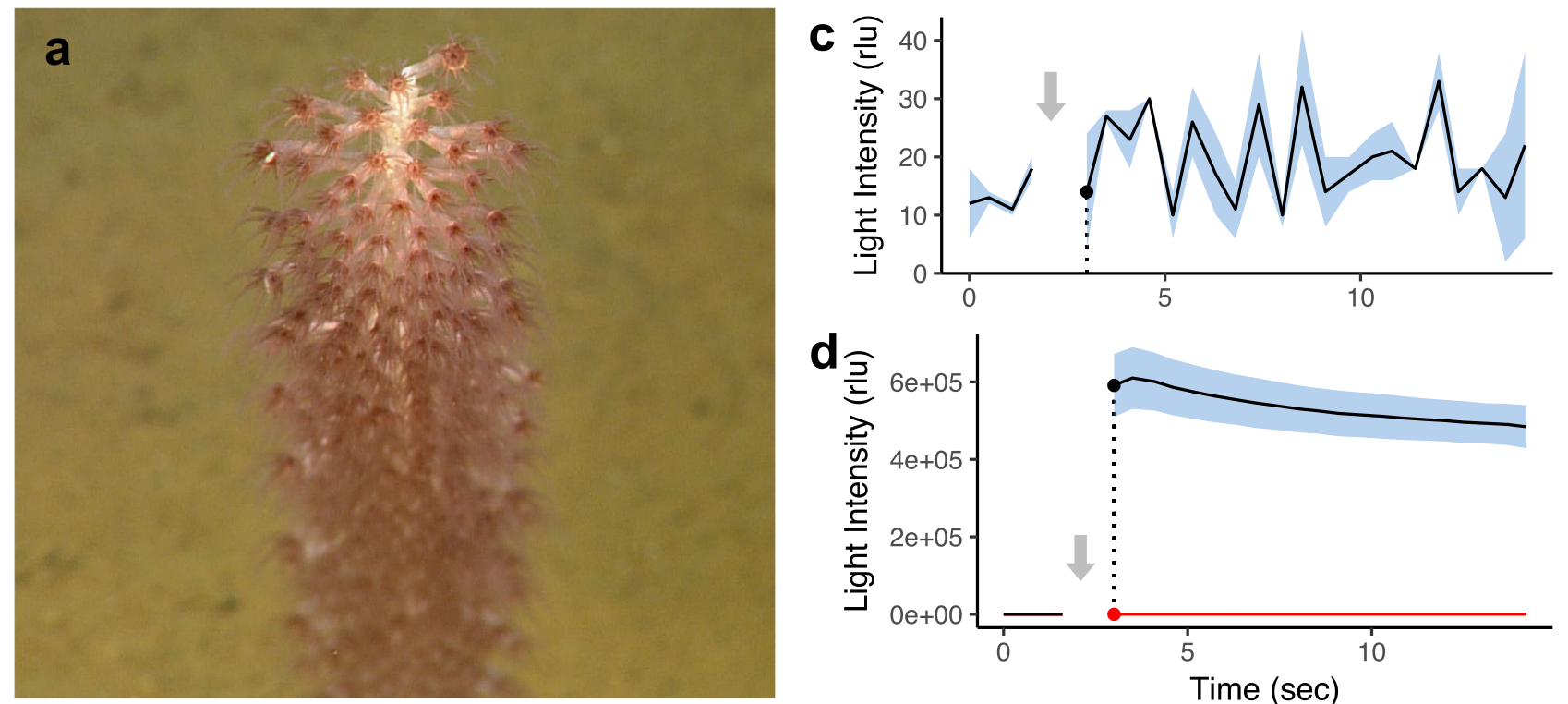

b

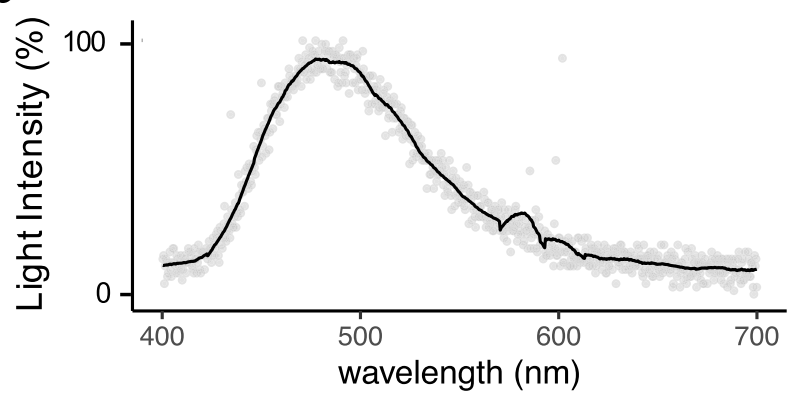

d

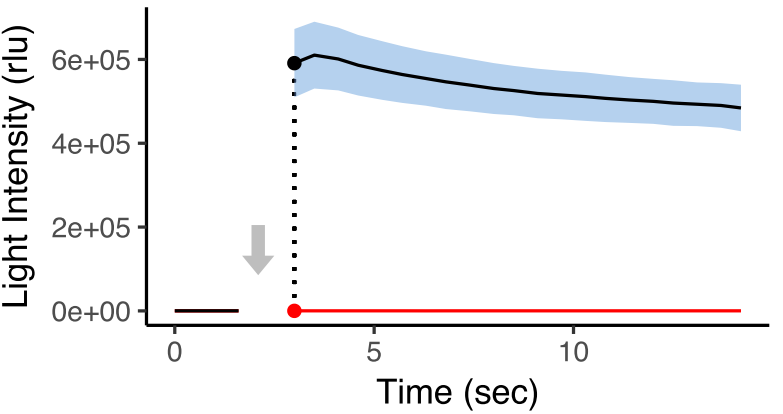

e

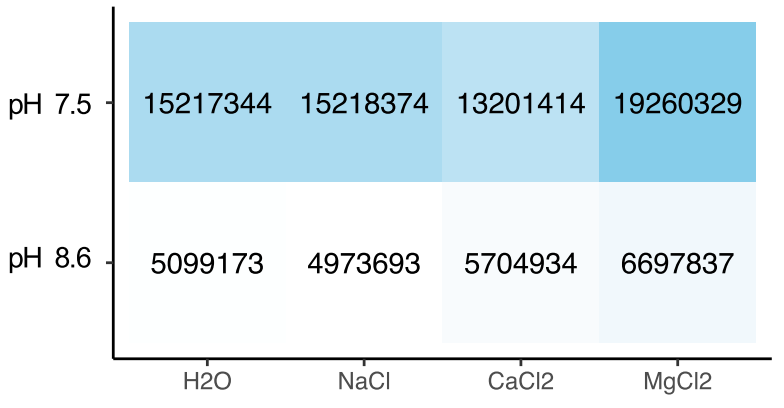

Fig. 8 Funiculina sp. a Frame grab of ROV dive at 879 m. b Bioluminescence spectrum. c Coelenterazine assay. d Luciferase assay. e The effects of $\mathrm{pH}$ and ions

Ethanol extract was positive for coelenterazine (Fig. $2 \mathrm{~g}$ ). The luciferase assay was positive, with the crude protein extract emitting light upon addition of coelenterazine (Fig. 2h). The luciferase activity was higher at $\mathrm{pH} 7.5$ than pH 8.6. Luciferase activity was sensitive to $\mathrm{Ca}^{2+}$ and $\mathrm{Mg}^{2+}$ at $50 \mathrm{mM}$ (Fig. 2i).

\section{Heteropolypus ritteri}

The mushroom coral Heteropolypus ritteri (Fig. 3a, b) extends polyps in situ but those polyps were retracted in the lab on the ship. Blue light was emitted from the autozooids and siphonozooids but not mesozooids when the specimen was stimulated with $\mathrm{KCl}$ (Fig. 3c). The light emission was slow and dim though nonetheless visible by eye. This is the first report of bioluminescence in genus Heteropolypus although this genus was recently reclassified from Anthomastus which is known to bioluminescence (Molodtsova 2013; Herring 1987). The specimen did not show fluorescence under either UV or blue light. The peak wavelength of the bioluminescent spectrum was at $476 \mathrm{~nm}$ (Fig. 3d).

The coelenterazine assay (Fig. 3e) and the assay for luciferase activity (Fig. 3f) were both positive. The peak wavelength of the in vitro luminescent spectrum was $475 \mathrm{~nm}$, almost identical to the bioluminescent spectrum. The luciferase activity was higher at $\mathrm{pH} 7.5$ than $\mathrm{pH} 8.6$ (Fig. 3g).

\section{Kophobelemnon sp.}

The specimen of Kophobelemnon sp. was collected at $3980 \mathrm{~m}$ depth (Fig. 4a), which is practically the deepest depth that ROV Doc Ricketts can access. Green fluorescence was expressed at the basis between tentacles and were distributed at the siphonozooid under blue light through a yellow filter (Fig. 4b, c). During in situ observations, the specimen emitted green light from the photophores located between tentacles (Fig. 4d) when the specimen was agitated by the manipulator of the ROV (Electronic Supplementary 

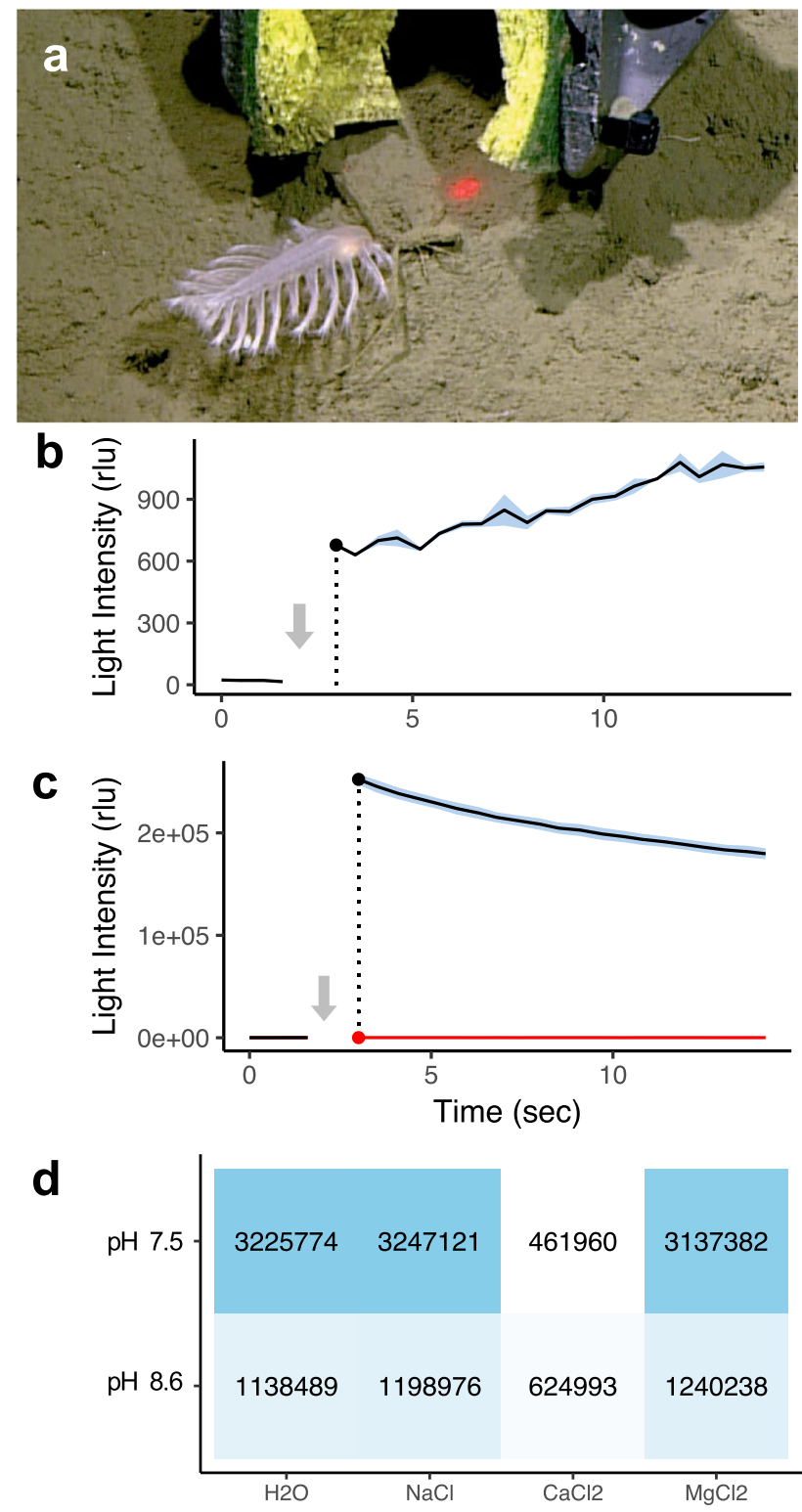

Fig. 9 Pennatula sp. a Frame grab of ROV dive at 3457 m. b Bioluminescence spectrum. c Coelenterazine assay. $\mathbf{d}$ Luciferase assay. $\mathbf{e}$ Effect of $\mathrm{pH}$ and ions

Material Video). This is the first report of bioluminescence in genus Kophobelemnon. The peak wavelength of the fluorescent spectrum was $538 \mathrm{~nm}$ (Fig. 4e). If this green fluorescence is produced by the GFP family, as suggested by the shape of the spectrum, then Kophobelemnon sp. possesses the deepest GFP yet found in the ocean.

The presence of coelenterazine was not supported by the coelenterazine assay (Fig. 4f). The luciferase assay was positive using crude protein extract (Fig. $4 \mathrm{~g}$ ). Luciferase activity was detected from rod tissue in which fluorescent siphonozooids are distributed but bioluminescence was not observed from this tissue in situ or in vivo. The luciferase activity was high at $\mathrm{pH} 8.6$ with $50-\mathrm{mM} \mathrm{CaCl}^{2}$ or $\mathrm{MgCl}^{2}$ (Fig. 4h). Interestingly, the luciferase activity in the $\mathrm{pH} 8.6$ buffer was lower than that in $\mathrm{pH} 7.5$ although the relationship of $\mathrm{pH}$ on the activity was opposite when the calcium or magnesium cations were present.

\section{Paragorgia arborea}

The bubblegum coral Paragorgia arborea (Fig. 5a) emitted blue light upon mechanical stimulation by the ROV manipulator (Fig. 5b). This is the first report of bioluminescence in suborder Scleraxonia.

The coelenterazine assay (Fig. 5c) and the assay for luciferase activity (Fig. 5d) were both positive. The luciferase activity was higher at pH 7.5 than pH 8.6 (Fig. 5e). Divalent cations such as calcium and magnesium cations positively affect luciferase activity.

\section{Umbellula sp.}

The Umbellula sp. (Fig. 6a, b) showed green fluorescence on the tentacles of polyps and basal of polyps on the stalk (Fig. 6c). Green bioluminescent light was also emitted from the polyps upon mechanical stimulation by the ROV manipulator. The peak wavelength of the bioluminescent spectrum was at $502 \mathrm{~nm}$ with a long-wavelength shoulder, characteristic of the presence of GFP (Fig. 6e), and corresponded closely with the measured fluorescence peak of $505 \mathrm{~nm}$. These values are also close to the 501-nm light measured from the stalk in Umbellula magniflora (Widder et al. 1983).

The coelenterazine assay (Fig. 6e) and the assay for luciferase activity (Fig. 6f) were both positive. The luciferase activity was higher at $\mathrm{pH} 7.5$ than $\mathrm{pH} 8.6$ (Fig. 6g). The luciferase activity was sensitive to calcium and magnesium cations.

\section{Distichoptilum gracile}

Distichoptilum gracile (Fig. 7a) emitted green light waves upon mechanical stimulation by the ROV manipulator (Fig. 7b, Electronic Supplementary Material Video). In the laboratory, touching the polyps elicited bright green light, visible by eye. The addition of a few drops of $\mathrm{KCl}$ triggered bright sustained bioluminescence, lasting a few minutes. A luminous mucus was released, though a green glow was also visible at the sites of fluorescence on the stalk. The peak wavelength of the bioluminescent spectrum was at $507 \mathrm{~nm}$ with a long-wavelength shoulder (Fig. 7c), identical to the fluorescent spectrum (Fig. 7d), and again, strongly suggestive of the presence of a green fluorescent protein.

The coelenterazine assay was positive, although the activity was very weak (Fig. 6e). The luciferase assay was 


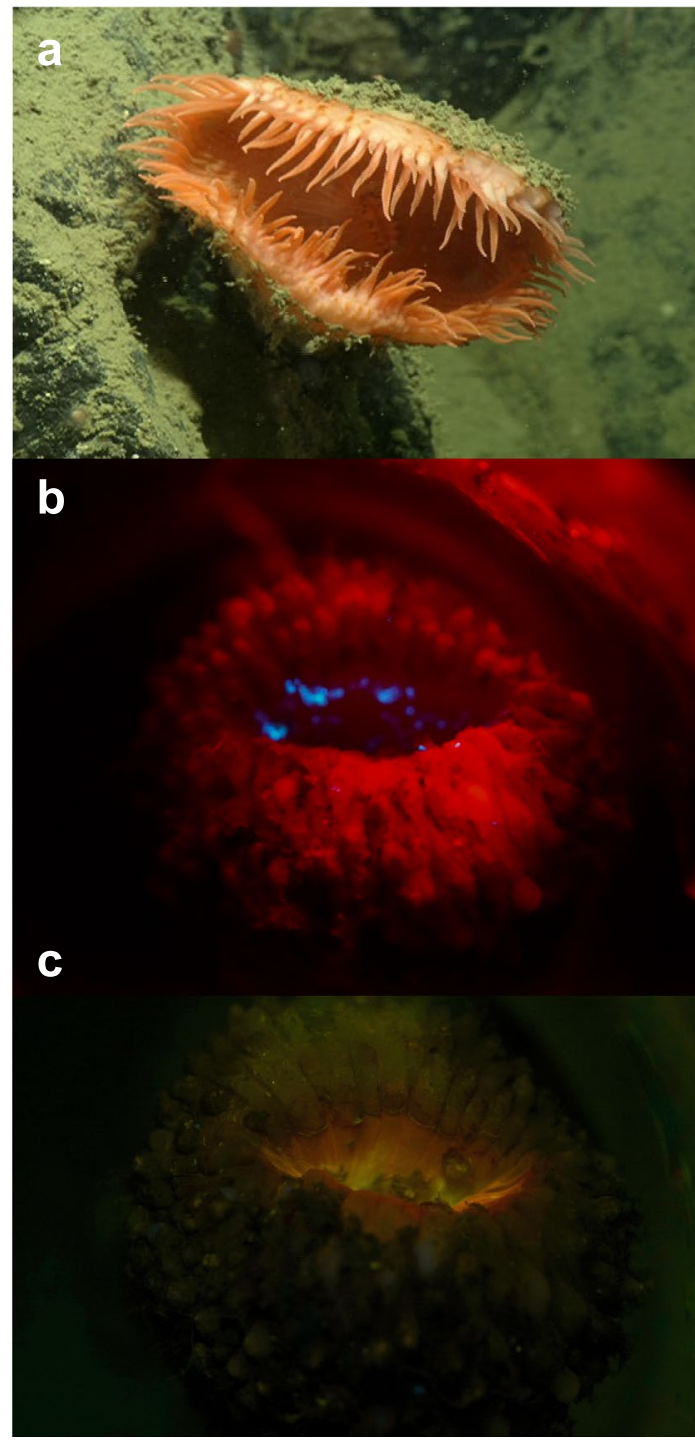

Fig. 10 Hormathiidae. a Frame grab of ROV dive at $1287 \mathrm{~m}$. b Bioluminescence stimulated with $\mathrm{KCl}$. ISO $25600, \mathrm{~F} / 2.8$, exposure time $2 \mathrm{~s}$. c Fluorescence of oral disc excited with blue light. d In vivo bio-

positive with the crude protein extract (Fig. 6f). The luciferase activity was higher at $\mathrm{pH} 7.5$ than $\mathrm{pH} 8.6$ (Fig. 6g). The luciferase activity was sensitive to calcium and magnesium cations. The luminescent spectrum of the in vitro luciferase assay was measured, and had a peak wavelength of $487 \mathrm{~nm}$, without a shoulder (Fig. 7h). The different spectra between in vivo and in vitro luminescence is due to energy transfer (Ward and Cormier 1979). Bioluminescent resonant energy transfer (BRET) occurs when luciferase and GFP are closely co-localized, less than $100 \AA$ apart. Under these conditions, excited energy resulting from the luciferin-luciferase reaction is transferred to excite the fluorophore in GFP, which is
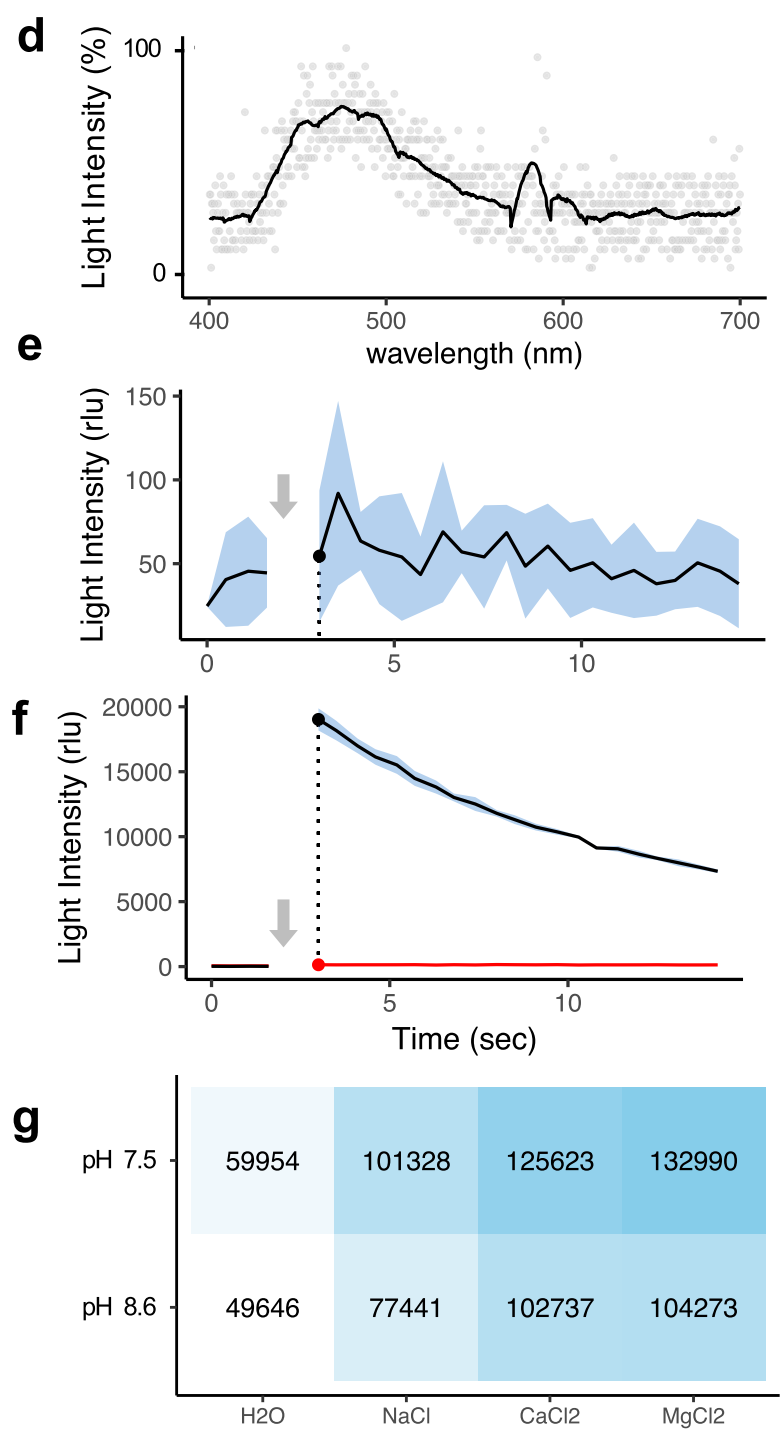

luminescence spectra. e Coelenterazine assay. f Luciferase assay. g Effect of $\mathrm{pH}$ and ions

well demonstrated in vitro using the aequorin system from Aequorea jellyfish (Morise et al. 1974). This connection is lost in in vitro assays, leading to shorter wavelength bioluminescence emission.

\section{Funiculina sp.}

Funiculina (Fig. 8a) emitted blue light upon mechanical stimulation of the stalk or polyps. Polyps rapidly contracted, but gentle squeezing could trigger light emission from the stalk. The peak wavelength of the bioluminescent spectrum was $485 \mathrm{~nm}$ (Fig. 8b). The addition of $\mathrm{CaCl}_{2}$ and coelenterazine 
Table 1 Taxonomy, habitat, bioluminescence spectra of coral specimens

\begin{tabular}{|c|c|c|c|c|c|}
\hline Species & Family & $\begin{array}{l}\text { Depth collected } \\
\text { (m) }\end{array}$ & Major observation $^{\mathrm{b}}(\mathrm{m})$ & $\begin{array}{l}\text { Bioluminescent } \\
\text { spectra }(\mathrm{nm})\end{array}$ & Accession no. ${ }^{c}$ \\
\hline Lepidisis sp. & Isididae & 1288 & $1250-2440$ & 477 & MN955305 \\
\hline Isidella tentaculum & Isididae & 1224 & $860-1230$ & Blue-green & MN955304 \\
\hline Heteropolypus ritteri ${ }^{\mathrm{a}}$ & Alcyoniidae & 1037 & $520-1510$ & 476 & MN955303 \\
\hline Kophobelemnon sp. ${ }^{\mathrm{a}}$ & Kophobelemnidae & 3980 & $2670-3970$ & Green & MN955300 \\
\hline Paragorgia arborea $^{\mathrm{a}}$ & Paragorgodiidae & 1243 & $950-1360$ & Blue-green & MN955306 \\
\hline Umbellula sp. & Umbellulidae & 3266 & $3950-3970$ & 502 & MN955308 \\
\hline Distichoptilum gracile & Protoptilidae & 1945 & $690-3070$ & 507 & MN955301 \\
\hline Funiculina sp. & Funiculinidae & 879 & $830-1250$ & 485 & MN955302 \\
\hline Pennatula sp. & Pennatulidae & 3457 & $3210-3210$ & Green & MN955307 \\
\hline Hormathiid & Hormathiidae & 1287 & $1030-2710$ & 472 & MN954949 \\
\hline
\end{tabular}

${ }^{\mathrm{a}}$ Genus newly described as bioluminescent in this study

${ }^{\mathrm{b}}$ Major observation depth of 10 and 90 percentile frequencies of the animals found in Monterey Bay

${ }^{\mathrm{c}}$ Nucleic 28S ribosomal gene for octocorals and mitochondrial COIII gene for the hormathiid anemone were deposited in GenBank

was sufficient to yield light from a 1-cm-long piece of the stalk.

The coelenterazine assay was negative (Fig. 8c). The luciferase assay was positive with the crude protein extract (Fig. 8d). The luciferase activity was higher at $\mathrm{pH} 7.5$ than at pH 8.6 (Fig. 8e).

\section{Pennatula sp.}

The sea pen Pennatula (Fig. 9a) emitted green bioluminescence. However, we could not determine the maximum wavelength due to weak luminescence.

The coelenterazine assay (Fig. 9b) and the assay for luciferase activity (Fig. 9c) were both positive. The luciferase activity was higher at $\mathrm{pH} 7.5$ than $\mathrm{pH} 8.6$ (Fig. 9d). Calcium cations negatively affected luciferase activity.

\section{Hormathiidae}

The hormathiid anemone (Fig. 10a), when mechanically stimulated using a paintbrush on the ROV arm, secreted a bright blue cloud from the mouth (Electronic Supplementary Material Video). The specimen discharged luminous mucus in the lab upon mechanical stimulation or chemical stimulation using potassium chloride (Fig. 10b). The discharge of blue luminous slime upon the mechanical stimulus has been reported from Hormathia alba (Tur 1993). The mouth emitted greenish-yellow fluorescence at the center with a gradation to orange fluorescence at the edge of the mouth under blue light (Fig. 10c). The peak wavelength of the bioluminescent spectrum was $472 \mathrm{~nm}$ (Fig. 10d).

The coelenterazine assay was negative with the ethanol extract (Fig. 10e). The luciferase assay was positive with the crude protein extract (Fig. 10f). The luciferase activity was higher at $\mathrm{pH} 7.5$ than $\mathrm{pH} 8.6$ (Fig. 10g). Ion strength increased luciferase activity.

\section{Bioluminescent behavior}

All of the deep-sea anthozoans tested in this study were bioluminescent (although some corals previously found not to be bioluminescent were not examined). Lepidisis sp., Isidella tentaculatum, Heteropolypus ritteri, Kophobelemnon sp., Paragorgia arborea, Umbellula sp., Distichoptilum gracile, Funiculina sp., Pennatula sp., and a Hormathiid anemone emitted light in situ when they were agitated by the arm of ROV or in vivo when they were mechanically and/or chemically stimulated in the laboratory.

The bioluminescence signals of Lepidisis and Isidella consist of waves of light emitted from the point of stimulation as described previously (Figs. 1a-c, 2d, Electronic Supplementary Material Video) (Muzik 1978). Distichoptilum also showed a wave-like flash pattern (Electronic Supplementary Material Video). Such a pattern is often observed in marine bioluminescent animals such as the shallow-water sea cactus Cavernularia, the sea pansy Renilla (Buck, 1973), the brittle star Amphipholis (Deheyn et al. 2000), the ctenophore Beroe forskalii, and deep-sea sea cucumber Pannychia (Herring 1995). The ecological significance of this display may be misdirection for predators, aposematic signal, or burglar alarm (Haddock et al. 2010), although there is no experimental evidence. Isidella, Distichoptilum, and the hormathiid secreted luminous clouds which contain homogenous luminous fluid and brighter particles (Electronic Supplementary Material Video). The secretion of luminous exudate in octocorals is reported here for the first time. The mucus contained luciferase activity using 
coelenterazine. The sticky, luminous mucus might serve as a deterrent to predators by marking the predator, which makes the predator vulnerable to attack from higher-order predators (Mensinger and Case 1992). The secretion of luminous fluid with particles is also known in ctenophores, scyphozoans, and polychaetes (Haddock and Case 1999; Herring and Widder 2004; Francis et al. 2014).

\section{Prevalence of blue or green light}

Hastings (1996) had noted a bimodal distribution in peak wavelength for pelagic and deep-sea organisms, where many species produced blue light, but others from similar habitats emitted green light. Of the species we collected, colors appeared to be related by site: Umbellula sp. and Pennatula sp. both produced green light and were collected from the same 3200-m site. However, at a relatively shallower site around $1200 \mathrm{~m}$, Isidella, Lepidisis, Heteropolypus, and the hormathiid all produced blue light (Table 1).

This suggests selective pressure on the wavelength. In coastal habitats, green is a more common color (Hastings 1996), for two reasons (Haddock and Case 1999). Firstly, shorter wavelength light is more easily scattered by particles, so environments with a high particle load may select for producing longer wavelengths. Secondly, shallow or coastal environments may broadly have higher primary productivity, and chlorophyll of phytoplankton is likely to absorb blue light, again favoring green over blue. For the deep sea, particles may be more abundant at some sites, and may favor longer wavelengths.
The bioluminescence spectra of Distichoptilum and Umbellula have a long-wavelength shoulder that is characteristic of GFP (Ward and Cormier 1979; Ogoh et al. 2013), suggesting that these two species possess GFP to modify the emitted light by resonant energy transfer. Of the many luminous cnidarians, three groups use GFP to modulate the color of bioluminescence: octocorals (as presented here), siphonophores, and many hydromedusae (e.g., Aequorea, Olindias, Clytia, Obelia), and other non-luminous anthozoans commonly possess GFP. Given the presence of GFP in cnidarians, but also in arthropods and chordates (Shagin et al. 2004; Deheyn et al. 2007), it is likely that GFP existed in the common ancestor of Cnidarians, and which could already could produce fluorescence (Shagin et al. 2004; Francis et al. 2016). This would mean that some species kept GFP for bioluminescence, use in general pigmentation (as fluorescence or chromoproteins for many hexacorals), or lost it.

\section{Occurrence of coelenterazine}

The presence of coelenterazine was determined for most of the octocorals tested in this study except Kophobelemnon, Funiculina, and the hormathiid anemone (Figs. 1g, 2f, 3e, 4f, 5b, 6e, 7e, 8c, 9b, 10e). These specimens might keep undetected luciferin in storage forms such as coelenterazine sulfate, which is found in Renilla and converted into coelenterazine by luciferin sulfokinase (Cormier et al. 1970). Coelenterazine content was determined by a substratespecific enzyme assay using Renilla reniformis luciferase. The results were summarized in Table 2 . All the values in

Table 2 Calculated content of coelenterazine and luciferase

\begin{tabular}{|c|c|c|c|c|c|c|c|}
\hline \multirow[t]{2}{*}{ Specimen } & \multicolumn{2}{|l|}{ CTZ assay } & \multicolumn{4}{|l|}{ Luciferase assay } & \multirow[t]{2}{*}{ Immunoreactivity } \\
\hline & Light intensity (rlu) & $\begin{array}{l}\mathrm{CTZ} \text { in } \\
\text { tissue (fmol/ } \\
\mathrm{mg})\end{array}$ & Light intensity (rlu) & Tissue (wt mg) & $\begin{array}{l}\text { Protein } \\
\text { Conc }(\mu \mathrm{g} / \\
\mathrm{mL})\end{array}$ & $\begin{array}{l}\text { Specific } \\
\text { activity (rlu/ } \\
\mu \mathrm{g})\end{array}$ & \\
\hline Lepidisis & $2.95 \times 10^{4}$ & 28 & $1.73 \times 10^{5}$ & 267 & 175 & $1.98 \times 10^{4}$ & Positive \\
\hline Isidella & $2.05 \times 10^{4}$ & 11 & $3.19 \times 10^{5}$ & 124 & 226 & $2.82 \times 10^{4}$ & Positive \\
\hline Heteropolypus & $9.94 \times 10^{4}$ & 210 & $1.88 \times 10^{9}$ & 188 & 280 & $1.34 \times 10^{8}$ & Positive \\
\hline Kophobelemnon & $8.72 \times 10^{2}$ & N.D & $4.28 \times 10^{5}$ & 230 & 454 & $1.89 \times 10^{4}$ & Positive \\
\hline Paragorgia & $6.76 \times 10^{3}$ & 16 & $1.39 \times 10^{5}$ & 202 & 366 & $7.58 \times 10^{3}$ & \\
\hline Umbellula & $1.67 \times 10^{5}$ & 189 & $3.75 \times 10^{4}$ & 173 & 282 & $2.66 \times 10^{3}$ & Positive \\
\hline Distichoptilum & $4.24 \times 10^{3}$ & N.D & $1.02 \times 10^{8}$ & 92 & 214 & $9.50 \times 10^{6}$ & Positive \\
\hline Funiculina & $4.19 \times 10^{2}$ & N.D & $1.17 \times 10^{7}$ & 221 & 430 & $5.45 \times 10^{5}$ & Positive \\
\hline Pennatula & $1.80 \times 10^{4}$ & 23 & $4.38 \times 10^{6}$ & 209 & 392 & $2.24 \times 10^{5}$ & \\
\hline Hormathiid & $1.12 \times 10^{3}$ & N.D & $1.97 \times 10^{3}$ & 214 & 78 & $5.02 \times 10^{2}$ & \\
\hline 10-nM Coelenterazine & $2.19 \times 10^{4}$ & & & & & & \\
\hline Renilla Luciferase & & & $3.18 \times 10^{5}$ & & 0.001 & $6.37 \times 10^{9}$ & Positive \\
\hline BSA & & & $2.72 \times 10^{3}$ & & 107 & $5.09 \times 10^{2}$ & \\
\hline
\end{tabular}

N.D. not detected 
Table 2 should be considered minimum values because of the consumption of substrate during collection, in situ bioluminescence tests, and spontaneous decomposition during storage and extraction. In our experimental conditions, the minimum detection limit of coelenterazine in the extract was $3 \mathrm{nM}$. The results for which we detected small amounts of coelenterazine suggest that anthozoans possess a storage form of coelenterazine, such as coelenterazine sulfate, which has been reported in Renilla (Inoue et al. 1977).

\section{Coelenterazine-dependent luciferases}

The activity of coelenterazine-dependent luciferase was tested using crude protein extracts. Assays for luciferase activity using coelenterazine resulted in light production from all the anthozoans (Fig. 11a, Table 2). The values of luciferase activity are significantly different among species. For example, the specific activity of Heteropolypus was 50,000 times higher than that of Umbellula. This variation is due to not only the differences in luciferase content of the tissues but also the differences in the optimum conditions for luciferase. For example, Kophobelemnon luciferase showed higher activity at $\mathrm{pH} 8.6$ although most of the others showed higher activity at $\mathrm{pH}$ 7.5. Thus, the values of specific activity in Table 2 do not represent an absolute value to compare luciferase activity between specimens but are nonetheless useful to identify bright systems for further study.

We biochemically investigated luciferase activities in the crude protein extract and found various responses under different conditions. Divalent cations (calcium and magnesium) negatively affected the luciferase from Lepidisis, Isidella, Umbellula, and Distichoptilum. Pennatula luciferase was selectively sensitive to calcium ion (Fig. 8d). Future studies of gene cloning, protein expression, and comparison of biochemical characters will help to explain how the amino acid sequence determines those properties, which will lead further development of new life science tools. It should be noted that we used crude protein extract that potentially contains more than two luciferase isoforms and other proteins which may affect luciferase activity.

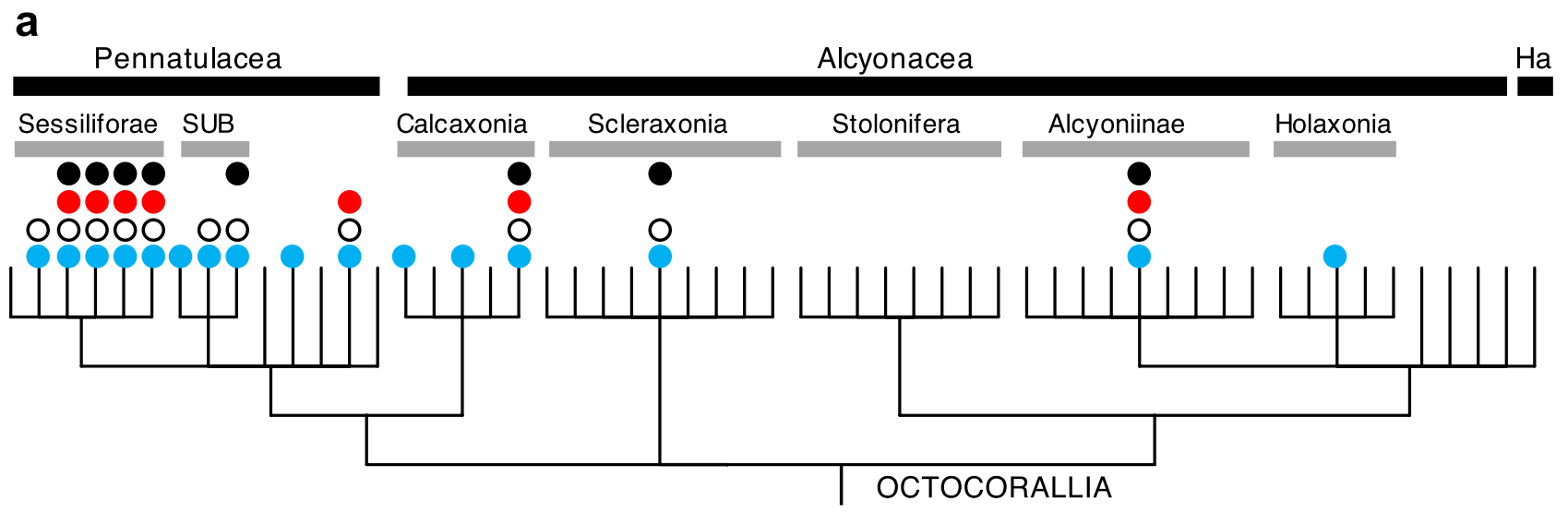

b

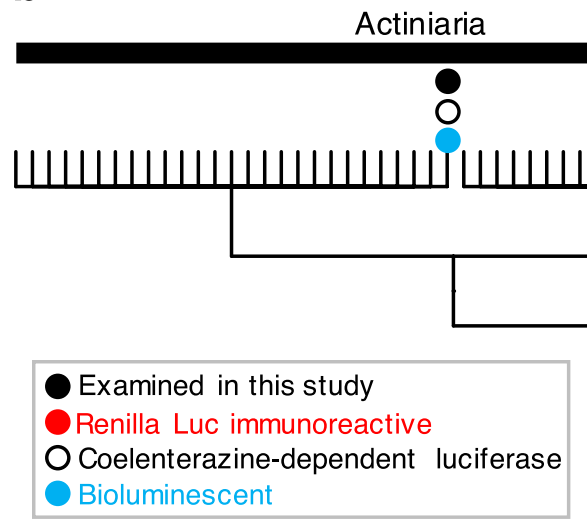

Scleractinia

Co Antp Zoantharia
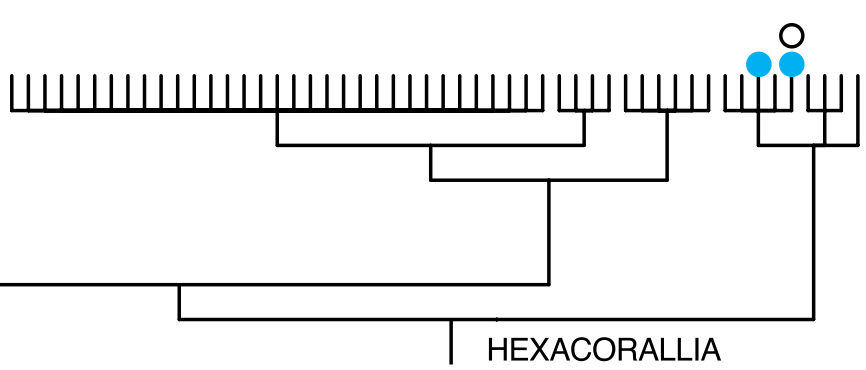

Fig. 11 Distribution of bioluminescence in $\mathbf{a}$ Octocorallia and $\mathbf{b}$ Hexacorallia. Families including bioluminescent taxa are indicated as blue filled circles. Taxonomy is assigned according to WoRMS. Phylogenetic relationship is derived from Quattrini et al. (2018). Black bars and gray bars indicate the classification of order and suborder. Antp Antipatharia, Co Corallimorpharia, Ha Helioproracea, SUB Subsessiliflora 
Western blotting analysis detected positive signals against the anti-Renilla luciferase antibody in protein extracts from Lepidisis, Heteropolypus, Kophobelemnon, and Distichoptilum (Fig. 11a, Electronic Supplementary Material Fig. S1). The bands in the blot have similar molecular size (32-40 kDa) to those of Renilla luciferase (37 kDa). Those immunoreactive bands indicate the presence of a luciferase which is homologous to Renilla luciferase. This finding suggests that it would be feasible to identify new luciferase genes using homology searches within anthozoan transcriptomes.

Our results provide fundamental information for seeking out new reporter genes of potential use for luminescence imaging. For example, calcium-ion specific sensitivity found in Pennatula luciferase could provide a calcium sensor, as alternative to aequorin, the Ca-triggered photoprotein. Cloning, protein expression, and precise characterization of pure luciferase will be needed to understand the property of each luciferase and to find new reporter genes to meet new imaging challenges.

\section{Evolution of bioluminescence in Octocorallia}

The presence of coelenterazine, coelenterazine-dependent luciferase activity, and immunoreactivity against antiRenilla luciferase antibody in protein extracts from luminous octocorals including Alcyonacea (Fig. 11a) suggests that all luminous octocorals share a common biochemical mechanism for bioluminescence. It leads two major hypotheses for the evolution of bioluminescence in octocorals: (1) the common ancestor of all the luminous octocorals was bioluminescent and that bioluminescence was lost multiple times in the course of evolution, or (2) luciferase activity evolved independently multiple times from a common non-luciferase homolog through parallel evolution.

In the order Pennatulacea, luciferase activity using coelenterazine was reported from the sea pens Renilla, Ptilosarcus, Stylatula, and Acanthoptilum (Cormier et al. 1973) and the sea cactus Cavernularia (Ogoh 2012). The luciferase genes from Renilla and Cavernularia have been cloned, and the amino acid sequences show $57 \%$ identity ( $81 \%$ similarity in BLOSUM62 matrix), suggesting that the most recent common ancestor of those corals had a single origin of bioluminescence.

We sought luciferase genes in the Renilla muelleri genome (Jiang et al. 2019) and found two additional para$\operatorname{logs}$ of luciferase. Those paralogs share $47-50 \%$ sequence identity and $72-78 \%$ similarity (BLOSUM62 matrix). The proposed catalytic triad (D120, E144, and H285 in R. muelleri luciferase; GenBank Accession number AAG54094) (Fanaei-Kahrani et al. 2018) was conserved in all three paralogs (Electronic Supplementary Material Fig. S2). However, two homologs were also found in the genome of the non-luminous soft coral Dendronephthya gigantea (Jeon et al. 2019), and these also have the same conserved catalytic triad. Further BLAST searches against the publicly available octocoral genome and transcriptome data found genes similar to Renilla luciferase. Phylogenetic analysis of those genes recovered the relationship that a luciferase homolog from Pennatula rubra is nested in the clade with validated luciferases of Renilla and Cavernularia (Electronic Supplementary Material Fig. S3).

Although several luciferase homologs were paraphyletic to the validated Renilla luciferase, experimental evidence is needed to determine whether those genes are functional as luciferases or not. Paralogous luciferase genes evolve differently regarding an enzymatic character and gene expression regulation, as shown in fireflies (Bessho-Uehara et al. 2017). There is still the possibility that the immunoreactive bands are false positives due to the presence of non-luminous homologs of Renilla luciferase, and that the true luciferases of Alcyonacea have a different origin than luciferases of Pennatulacea. Recent phylogenetic analyses pointed out that the order Alcyonacea is polyphyletic (McFadden et al. 2006; Quattrini et al. 2018). Keratoisidinae, including Isidella and Lepidisis, are suggested to form a clade with Pennatulacea; thus, it is considerably more plausible that those two groups share a common origin of bioluminescence.

Future studies on anthozoan phylogenetics will be needed to understand the evolution of bioluminescence within octocorals. Comparative transcriptome analysis with wide taxon sampling is desired to address those hypotheses, as we previously demonstrated in the case of independent origin of beetle bioluminescence (Fallon et al. 2018).

\section{Luciferase in hexacorallia}

Luciferase activity using coelenterazine was detected in the hormathiid anemone. The presence of coelenterazine-dependent luciferase in the hexacoral Parazoanthus (Fig. 11b) has previously been reported by Cormier et al. (1973). Immunoreactivity was not detected in protein extracts of the hormathiid specimen. BLAST searches against two publicly available transcriptomes from Hormathiidae anemones, Bolocera tuediae and Hormathia digitata, could not find any genes similar to Renilla luciferase. Another species, Hormathia alba, was the first reported luminous hormathiid (Tur 1993); so, H. digitata might be expected to be luminous as well. These results suggest that it is less likely that luciferases of those hexacorals share homology to Renilla luciferase, indicating an independent origin of bioluminescence origin in hexacorallia. Considering the phylogenetic distances between Hormathiidae and Parazoanthidae + Epizoanthidae (Macrocnemina: Zoantharia) (Fig. 11b), it is likely that the bioluminescence in hexacorallia evolved independently in each lineage. 
There are two well-characterized bioluminescence systems in Cnidaria: Renilla-type among octocorals and photoproteins among Hydrozoa. There are four additional evolutionary origins of bioluminescence in other Cnidaria: two origins in Hexacorallia, the unidentified luciferase of coronate scyphozoans such as Periphylla (Shimomura and Flood 1998), an unidentified mechanism of Pelagia noctiluca (Semaeostomeae: Scyphozoa), which was claimed by Morin and Hastings (1971) to be a photoprotein, though was never identified further. Thus, bioluminescence evolved at least six times in Cnidaria, but as many as 11 times, depending on the results from future studies. Surprisingly, all these animals use the identical molecule, coelenterazine, as the light-producing substrate, indicating that cnidarians provide an intriguing model group to study parallel evolution of bioluminescence. Detailed molecular characterization may be required to understand whether there are further novel mechanisms in those groups.

\section{Conclusions}

Bioluminescence in anthozoans is widely distributed, but biochemical aspects have been less studied, especially among deep-sea species. Here, we sampled deep-sea corals using a ROV down to $4000 \mathrm{~m}$ depth and observed bioluminescence in four genera not known to be luminous. A coelenterazine-dependent luciferase system was detected in all ten species of deep-sea octocorals and the hexacoral, and green-fluorescent protein was observed at nearly $4000 \mathrm{~m}$. We report for the first time the presence of coelenterazine-dependent luciferases in Alcyonacea and Hormathiidae. Immunoreactivity against Renilla luciferase in Alcyonacea suggests that all luminous octocorals share the similar biochemical mechanisms. While GFP is found consistently across cnidarians, and plausibly existed in the last common ancestor of cnidarians, the different mechanisms of bioluminescence are evidence for convergent evolution of light production during the course of diversification. Future studies including robust phylogeny, functional assays of luciferases, transcriptomes and genome analyses are needed to understand the evolution of anthozoan bioluminescence.

Acknowledgements We thank Jim Barry, Steven Litvin and Amanda Kahn for kindly providing coral specimens of Isidella and Paragorgia. We thank Lonny Lundsten and Kyra Schlining for species identification, and Shannon Johnson and Lynne Christianson for sequencing $28 \mathrm{~S}$ and COIII genes for taxonomic DNA identification. We thank anonymous reviewers for comments on the manuscript. We would like to express special thanks to the ROV pilots and ship crew. This work is supported by the David and Lucile Packard Foundation.
Data availability All data needed to evaluate the conclusions in the manuscript in the paper are present in the paper, the Electronic Supplementary Materials, and NCBI. DNA sequences are available in the NCBI GenBank repository, with accession numbers MN954949 and MN955300-MN955308. Additional data related to this paper may be requested from the authors.

\section{Compliance with ethical standards}

Conflict of interest All authors declare that they have no conflict of interest.

Open Access This article is licensed under a Creative Commons Attribution 4.0 International License, which permits use, sharing, adaptation, distribution and reproduction in any medium or format, as long as you give appropriate credit to the original author(s) and the source, provide a link to the Creative Commons licence, and indicate if changes were made. The images or other third party material in this article are included in the article's Creative Commons licence, unless indicated otherwise in a credit line to the material. If material is not included in the article's Creative Commons licence and your intended use is not permitted by statutory regulation or exceeds the permitted use, you will need to obtain permission directly from the copyright holder. To view a copy of this licence, visit http://creativecommons.org/licenses/by/4.0/.

\section{References}

Bellwood DR, Hughes TP (2001) Regional-scale assembly rules and biodiversity of coral reefs. Science 292:1532-1535

Bessho-Uehara M, Konishi K, Oba Y (2017) Biochemical characteristics and gene expression profiles of two paralogous luciferases from the Japanese firefly Pyrocoelia atripennis (Coleoptera, Lampyridae, Lampyrinae): insight into the evolution of firefly luciferase genes. Photochem Photobiol Sci 16:1301-1310. https ://doi.org/10.1039/C7PP00110J

Boussuet F 1520-1572 (1558) De Natura Aquatilium Carmen: in Vniuersam Gulielmi Rondeletii. Lugduni: Apud Matthiam Bonhome

Buck J (1973) Bioluminescent responses in Renilla. I. Colonial responses. Biol Bull 144:19-42

Burge CA, Mouchka ME, Harvell CD, Roberts S (2013) Immune response of the Caribbean Sea fan, Gorgonia ventalina, exposed to an Aplanochytrium parasite as revealed by transcriptome sequencing. Frontiers Physiol 4:1-9. https://doi.org/10.3389/ fphys.2013.00180

Conci N, Wörheide G, Vargas S (2019) New non-bilaterian transcriptomes provide novel insights into the evolution of coral skeletomes. BioRxiv. https://doi.org/10.1101/594242

Cordeiro R, McFadden C, van Ofwegen L, Williams G (2019) World List of Octocorallia. Accessed through: world Register of Marine Species at: https://www.marinespecies.org/aphia .php? $\mathrm{p}=$ taxdetails\&id=724715. Accessed 14 Nov 2019

Cormier MJ, Hori K, Karkhanis YD (1970) Bioluminescence of Renilla reniformis. VII. Conversion of luciferin into luciferyl sulfate by luciferin sulfokinase. Biochemistry 9:1184-1189

Cormier MJ, Hori K, Karkhanis YD, Anderson JM, Wampler JE, Morin JG, Hastings JW (1973) Evidence for similar biochemical requirements for bioluminescence among the coelenterates. J Cellular Physiol 81:291-297

Daly M, Brugler MR et al (2007) The phylum Cnidaria: a review of phylogenetic patterns and diversity 300 years after Linnaeus. Zootaxa 1668:127-182 
Deheyn D, Mallefet J, Jangoux M (2000) Expression of bioluminescence in Amphipholis squamata (Ophiuroidea: Echinodermata) in presence of various organisms: a laboratory study. J Mar Biol Ass UK 80:179-180. https://doi.org/10.1017/S002531549 9001733

Deheyn DD, Kubokawa K, McCarthy JK, Murakami A, Porrachia M, Rouse GW, Holland ND (2007) Endogenous green fluorescent protein (GFP) in amphioxus. Biol Bull 213:95-100

Delroisse J, Ullrich-Lüter E, Blaue S, Ortega-Martinez O, Eeckhaut I, Flammang P, Mallefet J (2017) A puzzling homology: a brittle star using a putative cnidarian-type luciferase for bioluminescence. Open Biol 7:160300. https://doi.org/10.1098/rsob.160300

Etnoyer PJ (2008) A new species of Isidella bamboo coral (Octocorallia: Alcyonacea: Isididae) from northeast Pacific seamounts. Proc Biol Soc Washington 121:541-553

Fallon TR, Lower SE, Chang CH, Bessho-Uehara M et al (2018) Firefly genomes illuminate parallel origins of bioluminescence in beetles. eLife 7:e36495. https://doi.org/10.7554/eLife.36495

Fanaei-Kahrani Z, Ganjalikhany MR, Rasa SM, Emamzadeh R (2018) New insights into the molecular characteristics behind the function of Renilla luciferase. J Cell Biochem 119:1780-1790

Francis WR, Powers ML, Haddock SHD (2014) Characterization of an anthraquinone fluor from the bioluminescent, pelagic polychaete Tomopteris. Luminescence 8:1135-1140

Francis WR, Christianson LM, Powers ML, Schnitzler CE, Haddock SHD (2016) Non-excitable fluorescent protein orthologs found in ctenophores. BMC Evol Biol 16:167

Geller JB, Walton ED (2001) Breaking up and getting together: evolution of symbiosis and cloning by fission in sea anemones (genus Anthopleura). Evolution 55:1781-1794

Haddock SHD, Case JF (1999) Bioluminescence spectra of shallow and deep-sea gelatinous zooplankton: ctenophores, medusae and siphonophores. Mar Biol 133:571-582

Haddock SHD, Moline MA, Case JF (2010) Bioluminescence in the sea. Annu Rev Mar Sci 2:443-493

Hastings JW (1996) Chemistries and colors of bioluminescent reactions: a review. Gene 173(5):5-11

Harvey EN (1952) Bioluminescence. Academic Press, New York, p 649

Herring PJ (1987) Systematic distribution of bioluminescence in living organisms. J Bioluminescence Chemiluminescence $1: 147-163$

Herring PJ (1995) Bioluminescent echinoderms: unity of function in diversity of expression. In: Emson R, Smith A, Campbell A (eds) Echinoderm research. A. A. Balkema Publishers, Brookfield, pp 9-17

Herring PJ, Widder EA (2004) Bioluminescence of deep-sea coronate medusae (Cnidaria: Scyphozoa). Mar Biol 146:39-51. https ://doi.org/10.1007/s00227-004-1430-7

Hongo Y, Yasuda N, Nagai S (2017) Identification of genes for synthesis of the blue pigment, Biliverdin IX $\alpha$, in the blue coral Heliopora coerulea. Biol Bull 232:71-81

Inoue S, Kakoi H, Murata M, Goto T, Shimomura O (1977) Complete structure of Renilla luciferin and luciferyl sulfate. Tetrahedron Lett 31:2685-2688

Inouye S (2007) Expression, purification and characterization of calcium-triggered luciferin-binding protein of Renilla reniformis. Protein Expr Purif 52:66-73

Jeon Y, Park SG, Lee N, Weber JA, Kim HS, Hwang SJ et al (2019) The draft genome of an octocoral, Dendronephthya gigantea. Genome Biol Evol 11:949-953

Jiang J, Quattrini AM, Francis WR, Ryan JF, Rodríguez E, McFadden CS (2019) A hybrid de novo assembly of the sea pansy (Renilla muelleri) genome. Giga Science 8:1-9

Johnsen S, Frank TM, Haddock SH, Widder EA, Messing CG (2012) Light and vision in the deep-sea benthos: I. Bioluminescence at 500-1000 m depth in the Bahamian Islands. J Exp Biol 215:3335-3343

Katoh K, Standley DM (2013) MAFFT multiple sequence alignment software version 7: improvements in performance and usability. Mol Biol Evol 30:772-780

Kumar S, Harrylock M, Walsh KA, Cormier MJ, Charbonneau H (1990) Amino acid sequence of the $\mathrm{Ca}^{2+}$-triggered luciferin binding protein of Renilla reniformis. FEBS lett 268:287-290

Lorenz WW, McCann RO, Longiaru M, Cormier MJ (1991) Isolation and expression of a cDNA encoding Renilla reniformis luciferase. Proc Nat Ac Sci 88:4438-4442

Matthews JC, Hori K, Cormier MJ (1977) Purification and properties of Renilla reniformis luciferase. Biochemistry 16:85-91

McFadden CS, France SC, Sánchez JA, Alderslade P (2006) A molecular phylogenetic analysis of the Octocorallia (Cnidaria: Anthozoa) based on mitochondrial protein-coding sequences. Mol Phylogenet Evol 41:513-527

Mesinger AF, Case JF (1992) Dinoflagellate luminescence increases susceptibility of zooplankton to teleost predation. Mar Biol 112:207-210

Molodtsova TN (2013) Deep-sea mushroom soft corals (Octocorallia: Alcyonacea: Alcyoniidae) of the Northern Mid-Atlantic Ridge. Mar Biol Res 9:488-515

Morin JG, Hastings JW (1971) Biochemistry of the bioluminescence of colonial hydroids and other coelenterates. J Cell Physiol 7:305-311

Morise H, Shimomura O, Johnson FH, Winant J (1974) Intermolecular energy transfer in the bioluminescent system of Aequorea. Biochemistry 13:2656-2662

Muzik K (1978) A bioluminescent gorgonian, Lepidisis olapa, new species (Coelenterata: Octocorallia), from Hawaii. Bull Mar Sci 28:735-741

Nguyen LT, Schmidt HA, von Haeseler A, Minh BQ (2015) IQ-TREE: a fast and effective stochastic algorithm for estimating maximumlikelihood phylogenies. Mol Biol Evol 32:268-274. https://doi. org/10.1093/molbev/msu300

Ogoh K (2012) Photoprotein and $\mathrm{Ca}^{2+}$-triggered coelenterazine-binding protein, and a research method using thereof. Japan patent JP2012110283-A/34 (Patent)

Ogoh K, Kinebuchi T, Murai M, Takahashi T, Ohmiya Y, Suzuki H (2013) Dual-color-emitting green fluorescent protein from the sea cactus Cavernularia obesa and its use as a $\mathrm{pH}$ indicator for fluorescence microscopy. Luminescence 28:582-591

Pratje A (1923) Das Leuchten der Organismen. Eine Übersicht über die neuere Literatur. Ergebnisse der Physiologie 21:1-108

Pratlong M, Haguenauer A, Chabrol O, Klopp C, Pontarotti P, Aurelle D (2015) The red coral (Corallium rubrum) transcriptome: a new resource for population genetics and local adaptation studies. Mol Ecol Resour 15:1205-1215

Quattrini AM, Faircloth BC, Duenas LF et al (2018) Universal targetenrichment baits for anthozoan (Cnidaria) phylogenomics: New approaches to long-standing problems. Mol Ecol Resour 18:281295. https://doi.org/10.1111/1755-0998.12736

Roberts JM, Wheeler AJ, Freiwald A (2006) Reefs of the deep: the biology and geology of cold-water coral ecosystems. Science 312:543-547. https://doi.org/10.1126/science.1119861

Romiguier J, Gayral P, Ballenghien M, Bernard A, Cahais V, Chenuil A, Chiari Y, Dernat R, Duret L, Faivre N, Loire E (2014) Comparative population genomics in animals uncovers the determinants of genetic diversity. Nature 515:261-263

Scholin CA, Herzog M, Sogin M, Anderson DM (1994) Identification of group- and strain-specific genetic markers for globally distributed Alexandrium (Dinophyceae). II. Sequence analysis of a fragment of the LSU rRNA gene. J Phycol 30:999-1011

Shagin DA, Barsova EV, Yanushevich YG, Fradkov AF, Lukyanov KA, Labas YA, Semenova TN, Ugalde JA, Meyers A, Nunez JM, 
Widder EA, Lukyanov SA, Matz MV (2004) GFP-like proteins as ubiquitous metazoan superfamily: evolution of functional features and structural complexity. Mol Biol Evol 21:841-850

Shimomura O, Flood PR (1998) Luciferase of the scyphozoan medusa Periphylla periphylla. Biol Bull 194:244-252

Simion P, Philippe H, Baurain D, Jager M, Richter DJ, Di Franco A, Roure B, Satoh N, Queinnec E, Ereskovsky A, Lapebie P (2017) A large and consistent phylogenomic dataset supports sponges as the sister group to all other animals. Cur Biol 27:958-967

Tur JM (1993) Redescription and biological aspects of Hormathia alba (Andres, 1881), a luminescent sea anemone (Anthozoa, Actiniaria). Helgoländer Meeresuntersuchungen 47:213-219

Watling L, France CS, Pante E, Simpson A (2011) Biology of deepwater octocorals. Adv Mar Biol 60:41-122

Ward WW, Cormier MJ (1979) An energy transfer protein in coelenterate bioluminescence. Characterization of the Renilla greenfluorescent protein. J Biol Chem 254(3):781-788

Widder EA, Latz MI, Case JF (1983) Marine bioluminescence spectra measured with an optical multichannel detection system. Biol Bull $165: 791-810$
Williams GC (1999) Index Pennatulacea - annotated bibliography and indexes of the sea pens of the world 1469-1999. Proc Calif Acad Sci 51(2):19-103

Williams GC (2001) First record of a bioluminescent soft coral: description of a disjunct population of Eleutherobia grayi (Thomson and Dean, 1931) from the Solomon Islands, with a review of bioluminescence in the Octocorallia. Proc Calif Acad Sci $52: 209-225$

Williams GC (2003) Capitate taxa of the soft coral genus Eleutherobia (Octocorallia: Alcyoniidae) from Palau and South Africa; a new species and a new combination. Zool Verh Leiden 345:419-436

Zapata F, Goetz FE, Smith SA, Howison M, Siebert S, Church SH et al (2015) Phylogenomic analyses support traditional relationships within Cnidaria. PLoS ONE 10:e0139068. https://doi. org/10.1371/journal.pone.0139068

Publisher's Note Springer Nature remains neutral with regard to jurisdictional claims in published maps and institutional affiliations. 